\title{
خمطوات
}

\section{دراست الحدل يث المعل}

\section{$\square$}

口اد. علي بن مصلح بن محمد الزبيدي

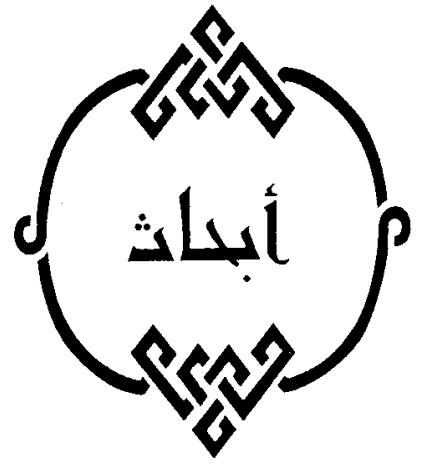

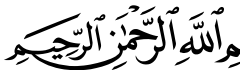

المقدمة:

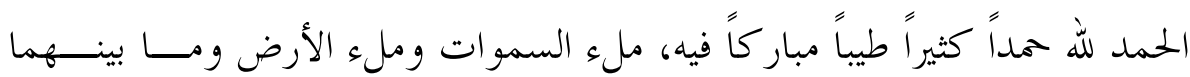
وملء ما شاء من شيء بعد. نحمده - سبحانه- و نستعينه ونستغفره، ونعوذ بالله مــن

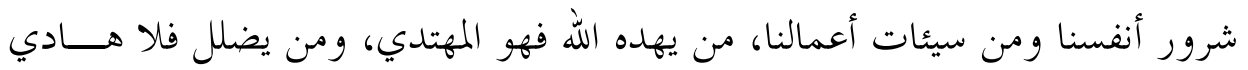

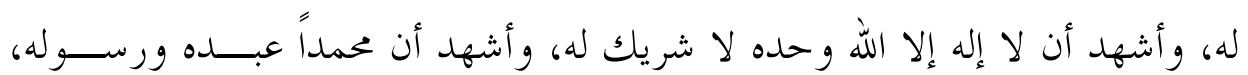
صلوات الله وسلامه عليه وعلى آل بيته الطيبين الطاهرين وصحبه ومن تبعه إلى يــوم

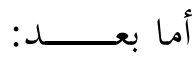

فإن من أشرف علوم الحديث وأدقها وأجلّها علم العلل الذي لا يقوم به إلا الأفذاذ من علماء هذا الشأن، قال ابن رجب -رحمه الله-: 》ا... وأردت بذلك تقريب علـــــ العلل على من ينظر فيه، فإنه علم قد هجر في هذا الزمان، وقد ذكرنا في كتاب العلم

(") السنة وعلومها - قسم أصول الدين - كلية الشريعة وأصول الدين - جامعة الملك خالد. 
أنه علم جليل قلَّ من يعرفه من أهل هذا الشأن، وأن بساطه قد طُوي منذ أزمانه|(') وإن مما يسر الباحث في الحديث الشريف ما يرى من المنهجية السليمة في دراســـة الحديث وعلومه، و العناية بعلوم سلفنا الزاخرة جمعاً ودر اسة وتحليلاً واستنباطاً. ومن ذلك العناية بعلم العلل الذي هو أدق علوم الحديث، فقد انتشر -بفضل اللهـبين طلبة الحديث العناية هذا الفن الدقيق، وحرص الباحثون في الدراسات العليا علــى تسجيل الموضوعات في هذا الفن. ولو أردت سرد الموضوعات في هذا الشأن لطال بنا المقام، حتى قال الدكتور أحمد محمد نور سيف -وفقه الله-: البدأنا نَقربُ من وضـــع

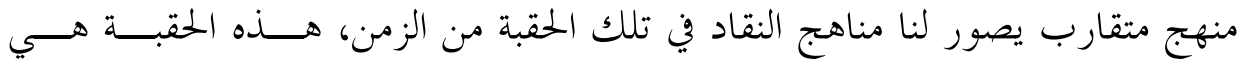

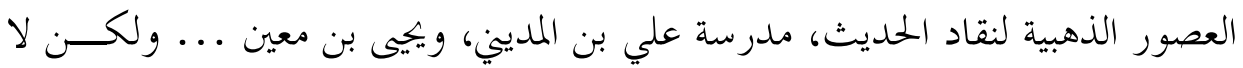

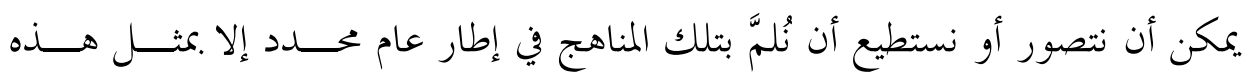
الدراسة .... (ب) و كانت هناك أسباب دعتي للكتابة في هذا الموضوع، منها:

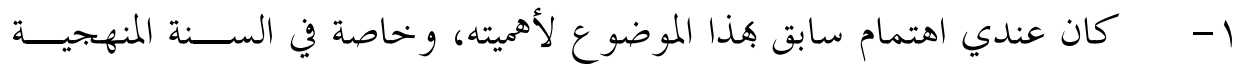

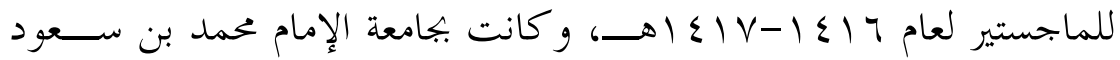
الإسلامية حيث شرفت بالدراسة على يد الشيخ الفاضل الدكتور / أحمد عبد

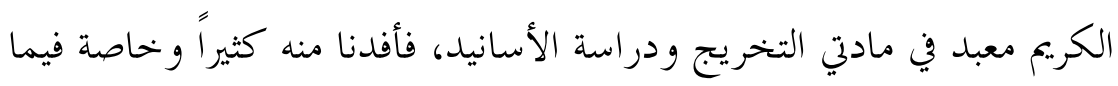
يتعلق بالأحاديث المعلة و المختلفة من أوجـــهـ متعـــددة، و كيفيــة دراســتها والخطوات العملية في ذلك.

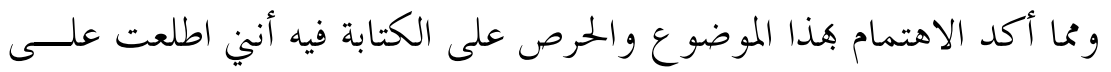

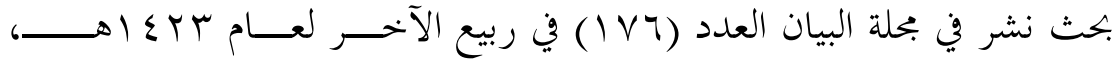


للدكتور / علي بن عبدالله الصيّاح. و وكان بعنوان (المنهج الســليم في دراســـة

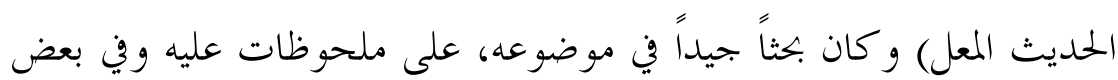
ما يقول لا يو افق عليه.

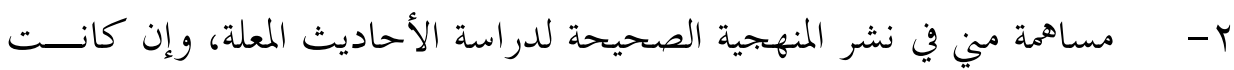

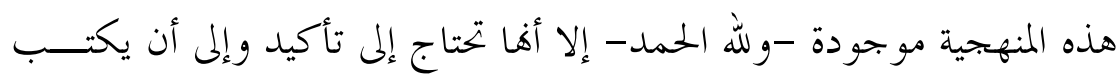
فيها استقلالاً وينشر بين طلاب العلم عامة، وطلاب الحدود الحديث خحاصة.

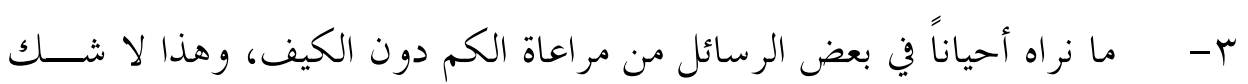

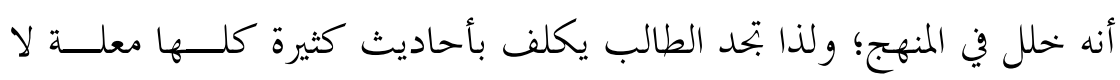
تفي المدة بدراستها وفق المنهجية الصحيحة، فيضطر إلى الإخلال بالمنهجيــة الصحيحة، حتى يتسنى له التسليم في المدة المحددة.

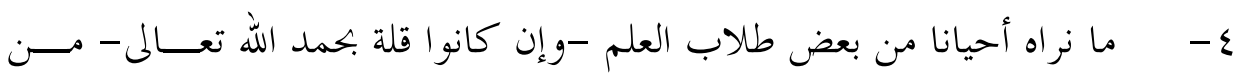

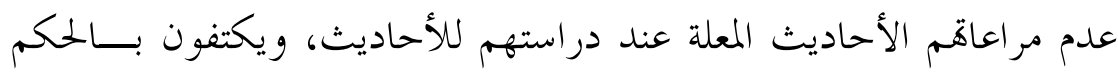
عليها بحسب ظاهر الإسناد، دون الرجوع إلى كتب العلل وتأمل كلام أئمــة

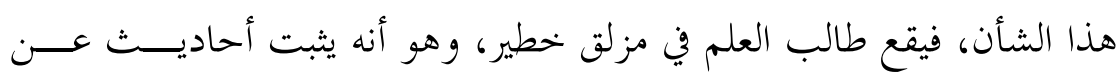
سيد المرسلين، وهي في حقيقة الأمر معلة عند أهل العلم. أما بالنسبة للمنهج الذي سلكته في هذا البحث، فهو على النحو التالي:

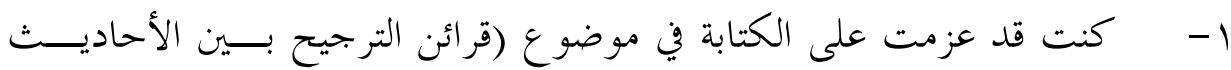
المعلة) وذكر مثال لكل قرينة، ولكن بعد استشارة بعض الأساتذة الفضلاء في هذا الموضوع، وموضوع آخر وهو (بيان المنهج السليم في دراسة الحـــــيث

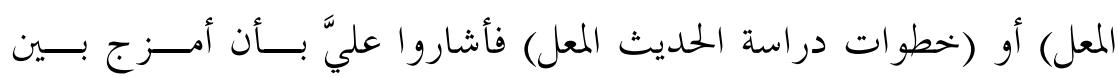

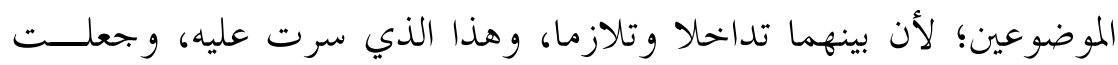
عنوان البحث (خطوات دراسة الحديث المعل). 
T- اكتفيت في ذكر القرائن بسردها لكثرها، دون الأمثلة حتى لا يطول البحث،

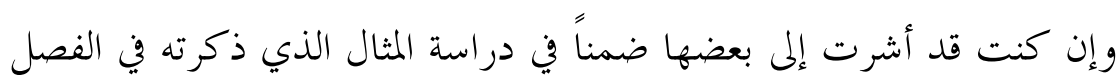
الثاني.

r- - مجعت في دراسة هذا الموضوع بين الجانب النظري والعملي، ففـــي الفصــل

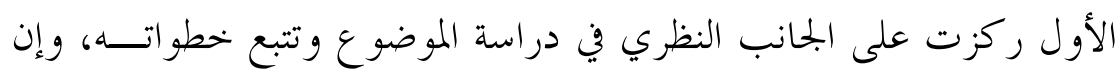

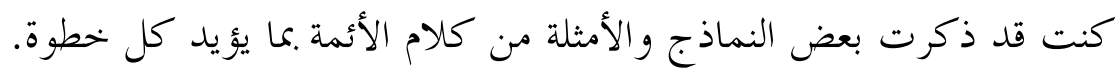

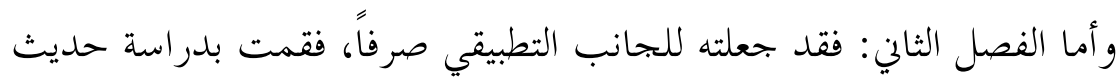

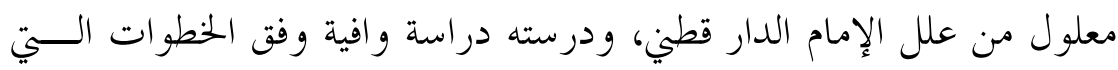

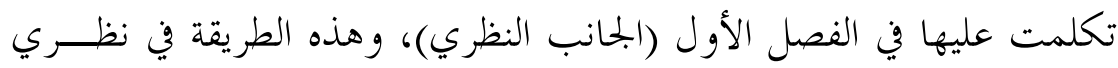

$$
\text { هي أجدى وأنفع في دراسة هذا الموضوع. }
$$

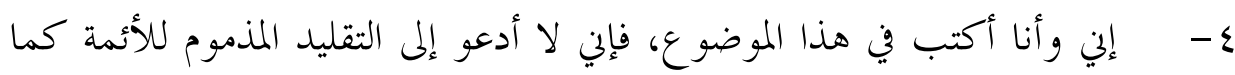

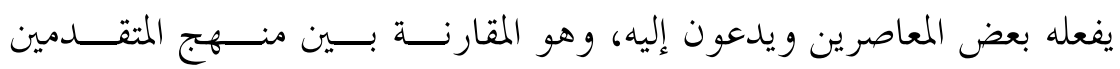

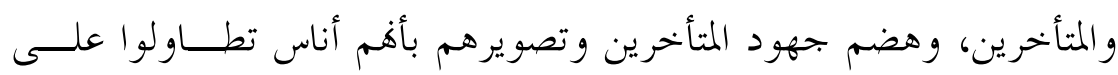

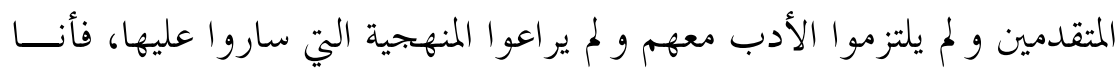

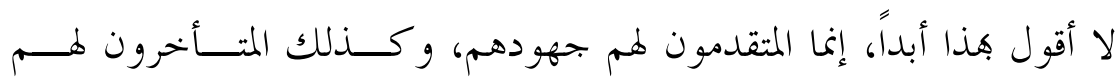

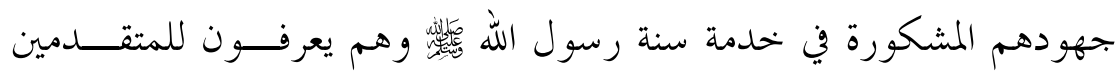

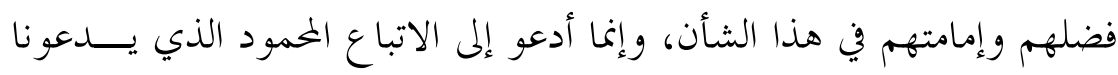
للاستفادة من علم المتقدمين، وعدم هضم حقوق المتأخرين، و الله أعلم.

\section{خطة البحث:}

\section{يتكون هذا البحث من مقدمة وفصلين وخاتمة، وفهرسين.}

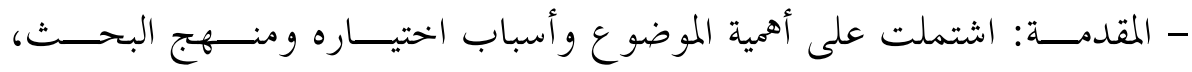


- الفصل الأول: (الجانب النظري) واشتمل على مبحثين: المبحث الأول: تعريف علم العلل، وأهميته، واشتمل على مطلبين: المطلب الأول: تعريف العلة لغة واصطلاحاً. المطلب الثاني: أهمية علم العلل. المبحث الثاني: بيان خطو ات دراسة الحديث المعل. - الفصل الثاني: (الجحانب العملي أو التطبيقي) وهو عبارة عن دراســة تفصــيلية لحديث معل مختار من علل الدارقطني. تم خحاتمــة: ضمنتها أهم النتائج. تم ذكرت فهرس المراجع، وفهرس الموضوعات.

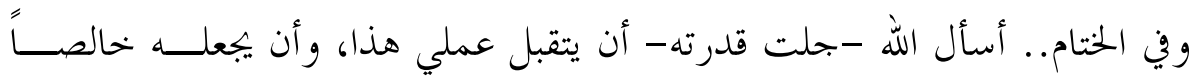

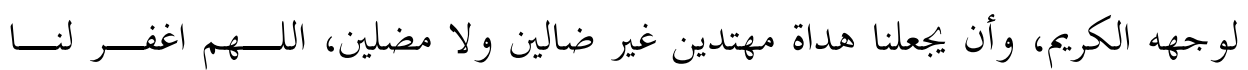
ولو الدينا ولمشائخنا وللمسلمين، آميـنـ.

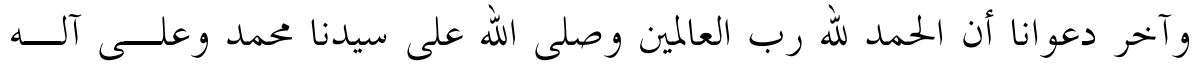
وصحبه أجمعين.

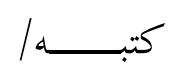

د.علي بن مصلح الزبيدي 


\section{الثضصل الأول \\ الجانـبـ النظـــري}

واشتمل على مبحثـــن:

المبحث الأول: تعريف علم العلل، وأهميته

المطلب الأول: تعريف العلة لغة واصطلاحاً:

تعريف العلة لغة:

قال ابن فارس في معجم مقاييس اللغة: علّّ: العين و اللام أصول ثلاثة صحيحة:

$$
\text { و والثانها: تكرار أو تكرير. }
$$

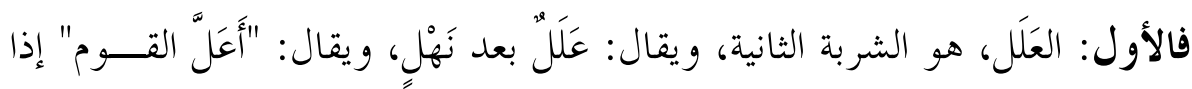

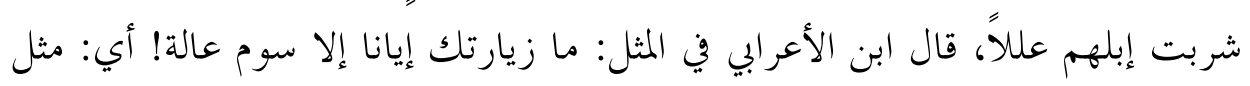

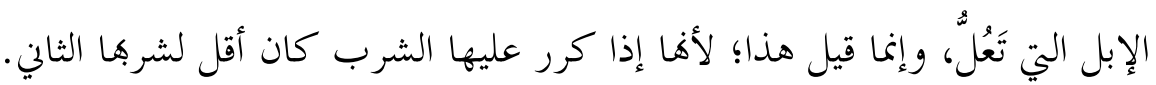
والثاني: العائق يعوق، قال الخليل: 》العلة حدث يشغل صاحبه عن وجهها《 ويقال: اعتل عن كذا. أي: اعتاقه، قال: فاعتله الدهر وللدهر عِلَّ.

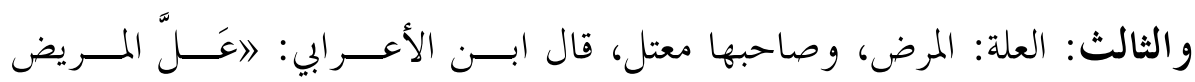

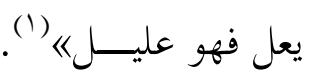

والحديث الذي تو جد فيه العلة يقال: معل، وهو القياس. كما يطلق عليه المعلّل؛ لأن العلة قد عاتقته وشغلته، فلم يعد صالحاً للعمل. 
وقال في القاموس: 》اعتل وأعلّه الله، فهو معلّ وعليل، ولا تقل: معلول و المتكلمون يقولوها، ولست منه على ثلج《" (1). وكثير من المحدثين يستعملون كلمة 》معلول《 للحديث الذي توجد فيه العلة، منهم البخاري، والترمذي، و الدارقطني، والحاكم، وغيرهم.

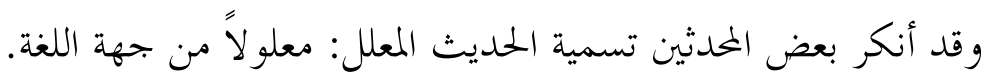
قال ابن الصلاح: والمعلول مرذول عند أهل العربية واللغة(؟).

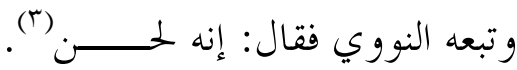
وقال العراقي: والأحسن في تسميته المعل (؛).

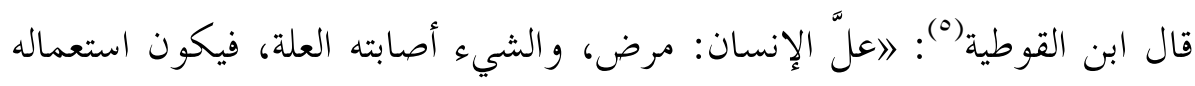

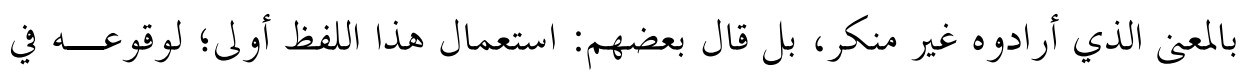
عبار ات أهل الفن، مع ثبوته لغة، ومن حفظ حجة على من لم يحفظ، قال ابن هشـــام في شرح بانت سعاد:

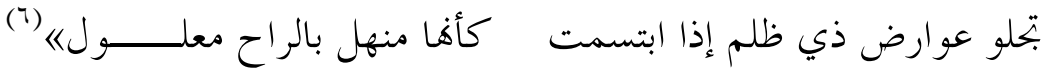

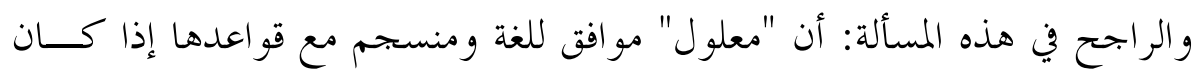

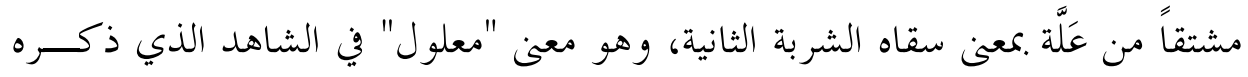

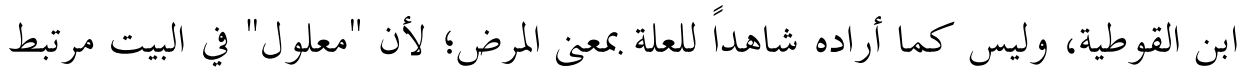
كمنهل، والمنهل هو المورود في المرة الأولى، والمعلول هو المورود في المرة الثانية.

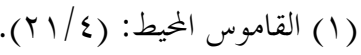

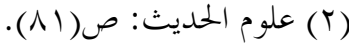

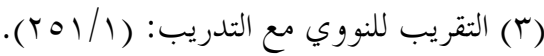

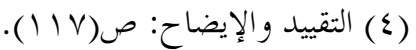

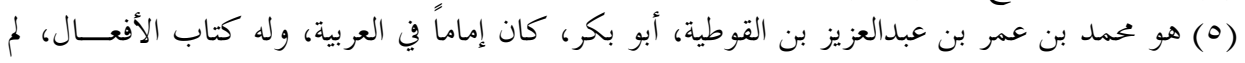

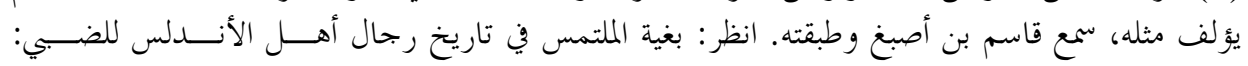


ولما كان من معاني "عَلَّ" في أصل اللغة الشربة الثانية، كما ذكر ابن فارس في معنى هذه المادة، فيكون هذا الاستعمال لا غبار عليه، لا في اللغة ولا في الاصطلاح، وتكون العلاقة بين المعنى اللغوي والاصطلاحي: أن العلّة ناشئة عن إعادة النظر في الحديث مرة لمدة بعد مرة. ويمكن أن يرد عليهم -أيضاً - بأن هذا الاصـــلاح للمحــــثين و لا مشـــاحة في الاصطلاح

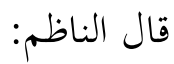

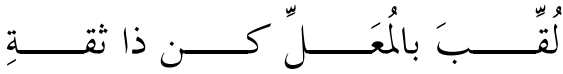

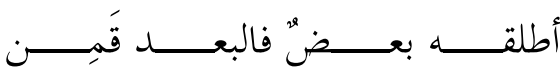

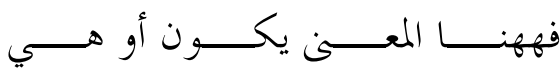
(وهذا البيت لا يو افت عليه كما أوضحنا ذلك سابقاً)

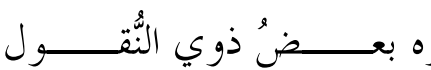

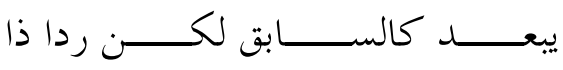

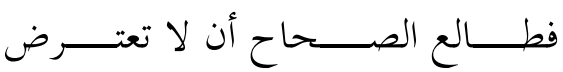

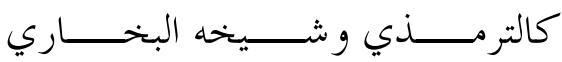

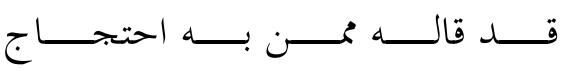

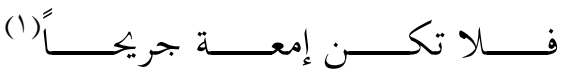

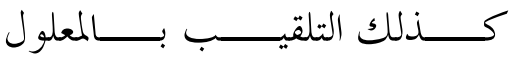

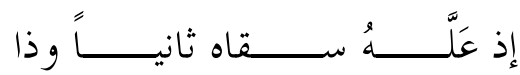

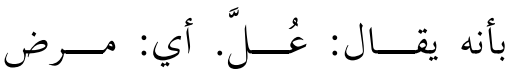

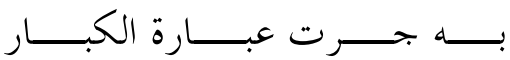

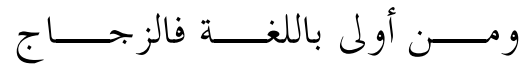

لذا نـــرى اسـتعماله صــحيحاً

تعريف العلة اصطلاحاً:

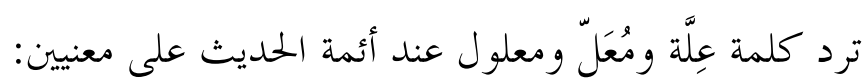

المعنى الأول: (معنى عام) ويراد به الأسباب التي تقدح في صحة الحديث المانعة من

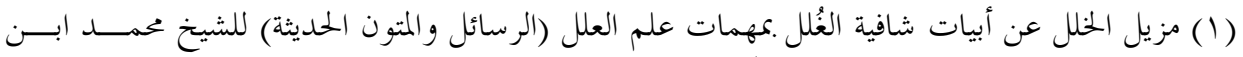

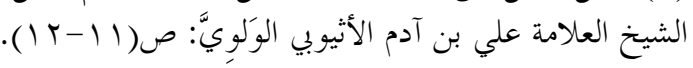


العمل به. قال ابن الصلاح: 》اعلم أنه قد يطلق اسم العلة على غير ما ذكرناه من باقي

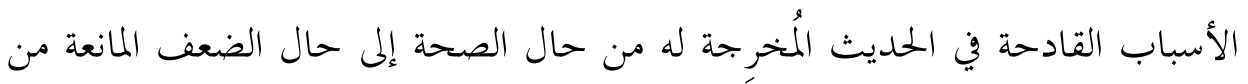
العمل به على ما هو مقتضى لفظ العلة في الأصل؛ ولذلك بند في كتب علل الحلديث

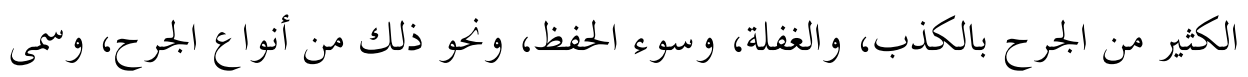

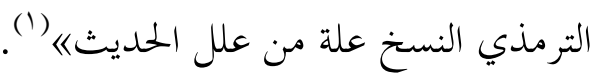

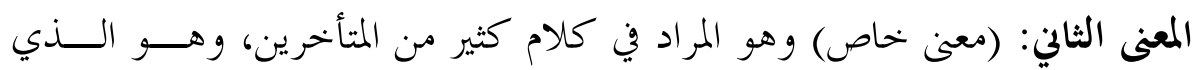
ذكروه في كتب المصطلح، وهو مراد من تكلم عن أهمية العلل ووقتها وقلة من بـــرز فيها.

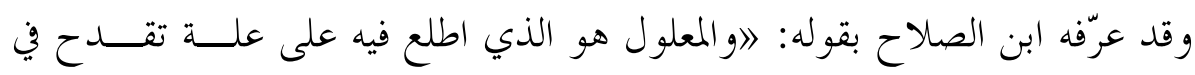

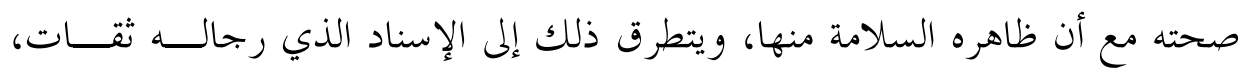
الجامع شروط الصحة من حيث الظاهره(r). فذكر هنا علة الإسناد و لم يشر إلى علة المتن.

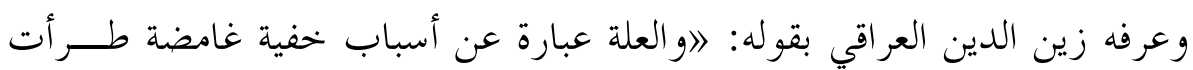

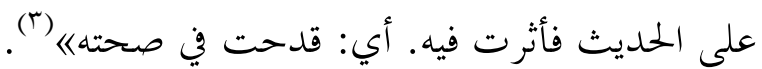

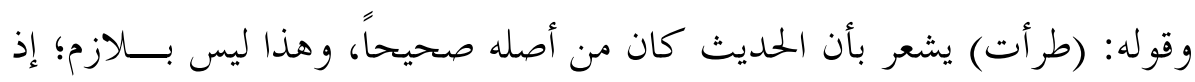

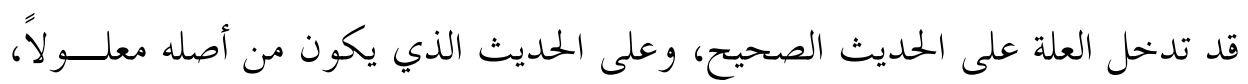

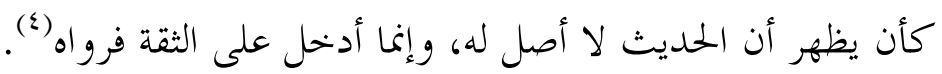

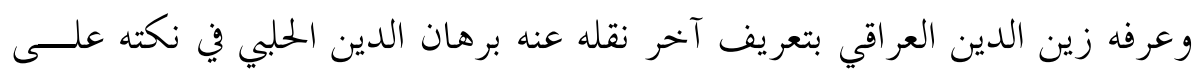

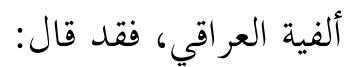

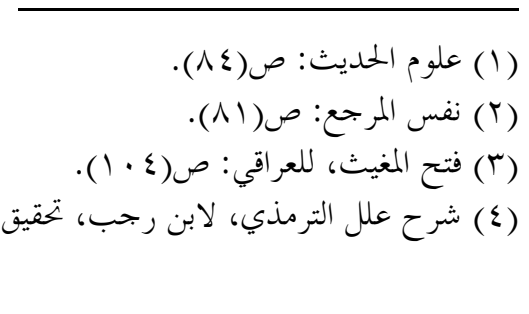


》و العلل خبر ظاهره السلامة اطلع فيه بعد التفتيش على قادح)" (1). وهو من أفضل من عرف الحديث المعل، وتبعه تلميذه ابن حجر -رحمه الله- فقـــــ عرفه بنفس تعريف شيخه (r). المطلب الثاني: أهمية علم العلل: يعتبر هذا العلم أدق وأجل علوم الحديث. قال الإمام عبدالرحمن بن مهدي: الأنْ أعرف علة حديث، هو عندي أحسبـ إليَّ من أكتب عشرين حديثاً ليست عنديه (r).

وقال الحاكم: 》(معرفة علل الحديث هو علم برأسه نار غير الصحيح") (؛). وقال الحافظ ابن حجر: ا(المعلل: وهو من أغمض أنواع علوم الحديث وأدقها، ولا

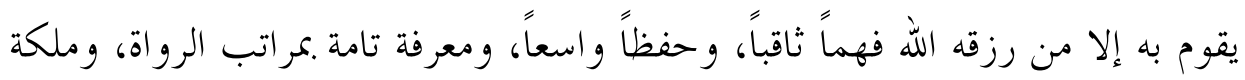
قوية بالأسانيد والمتون؛ وهذا لم يتكلم فيه إلا القليل من أهل هذا الشأن: كعلي ابــن المديني، وأحمد بن حنبل، والبخاري، ويعقوب بن شيبة، وأبي حاتم، وأبي زرعسـة... ${ }^{(0)}$ 《रे

\section{المبحث الثاني: بيان خطو ات دراسة الحديث المعل (†)} سننطلق في بيان هذه الخطو ات من نص إمامين من أئمة العلل همـــا: الإمــــام أبــو

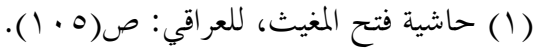

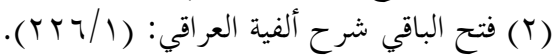

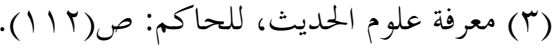

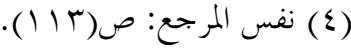

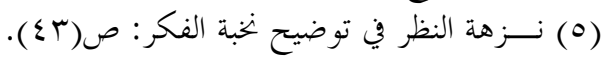

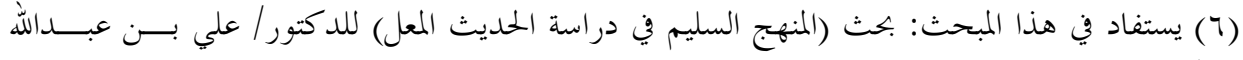

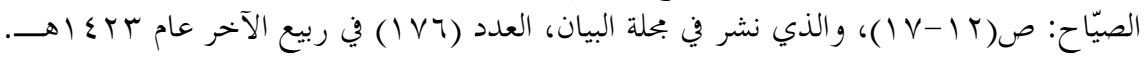


يوسف يعقوب بن شيبة السدوسي المتوف سنة (rTY بهــ) (1)، والإمام أبو الحسسن علي

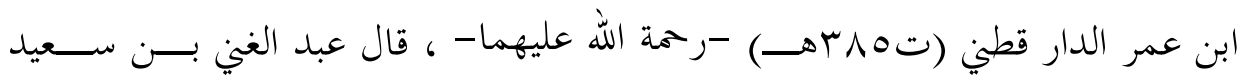

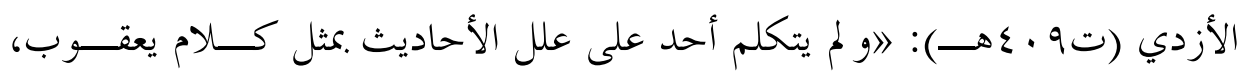

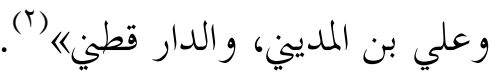

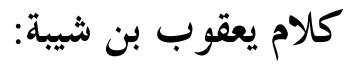

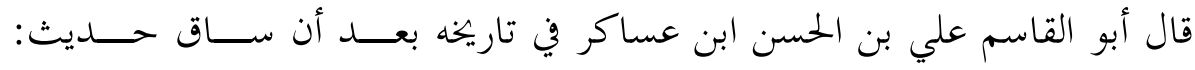
((تابعوا بين الحجج والعمرة)) من طريق أبي يوسف يعقوب إن بن شيبة السدوسي قال: القال

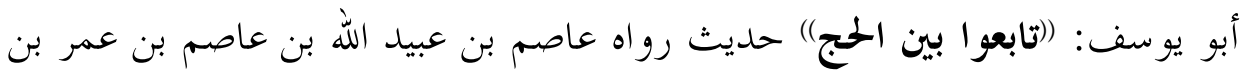

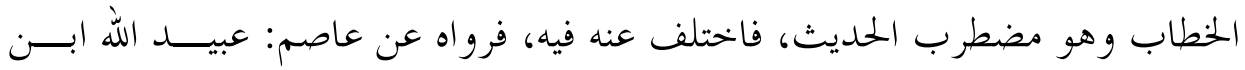

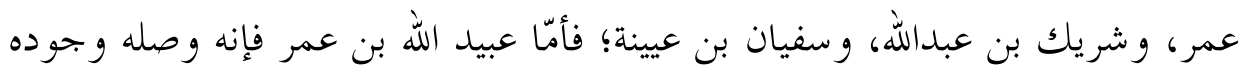

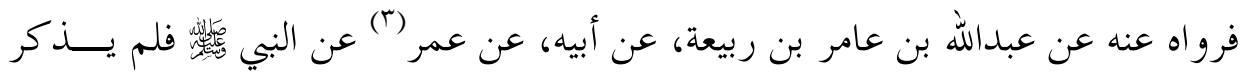

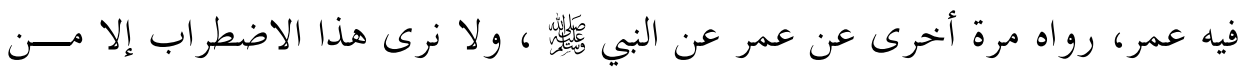

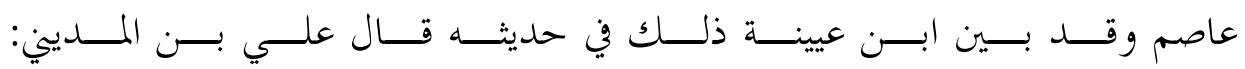

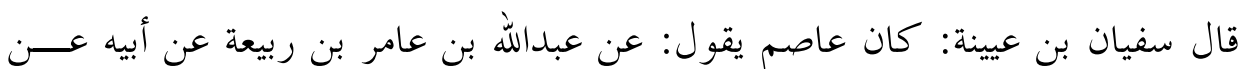

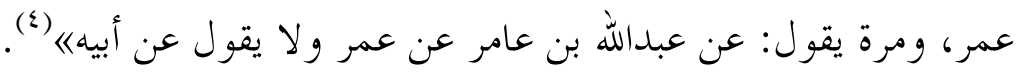

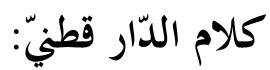

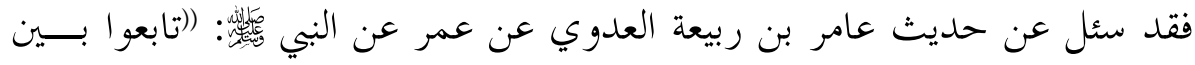

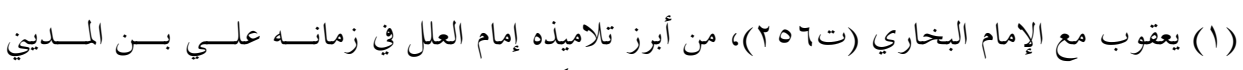

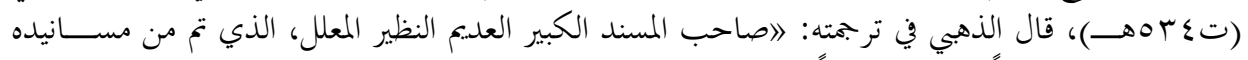

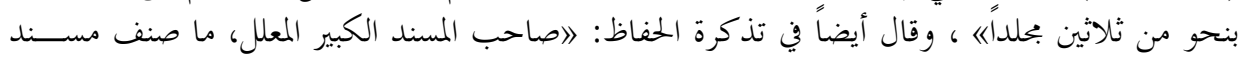

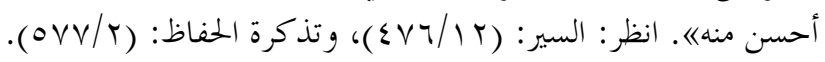

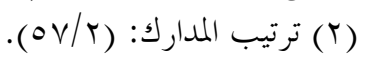

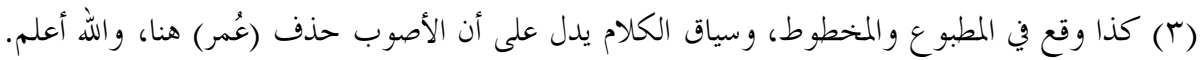

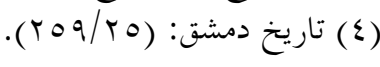


الحج والعمرة؛ فإذما ينفيان الفقر والذنوب) الحديث، فقال: (ا يرويه عاصم بن عبيد

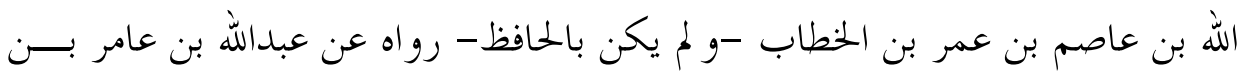

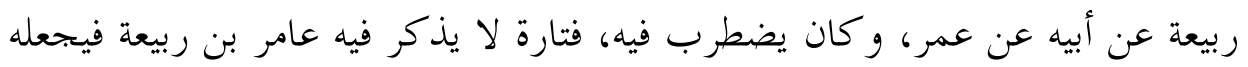

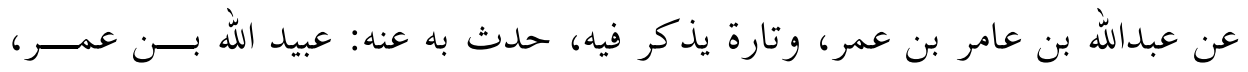

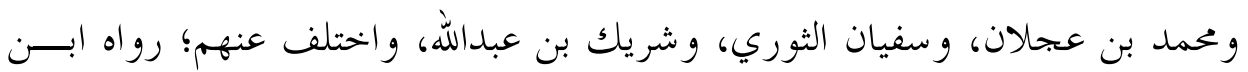
عيينة عنه فبان الاضطراب في الإسناد من قبل عاصم بن عبيد الله لا من قبل مـــن رواه

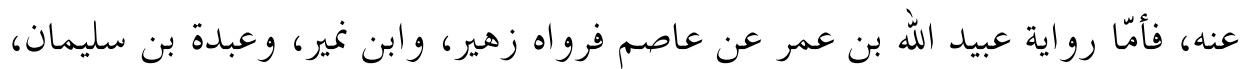

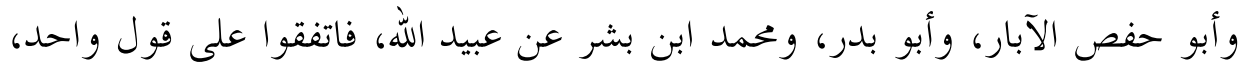

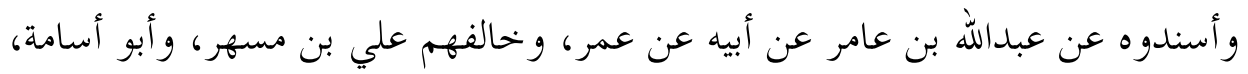

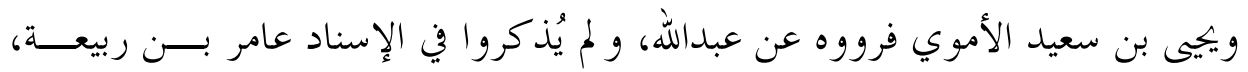

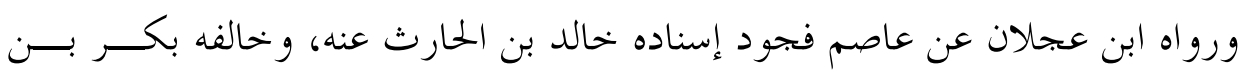

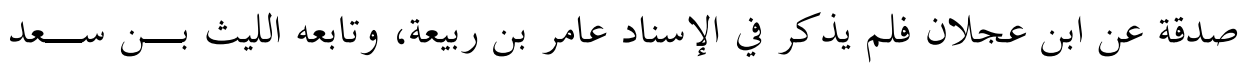
على إسناده إلا أنه وقفه، ورواه الثوري عن عاصم و اختتلف عنه؛ فقال حســيـن بــن حفص: عن سفيان عن عاصم عن عبدالله بن عامر عن أبيه عن عمر، وخحالفه أبو أحمد الزبيري فرواه عن الثوري فنقص من إسناده عامر بن ربيعة، ورواه محمد بن كثير عــنـ

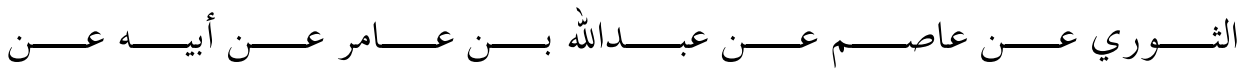

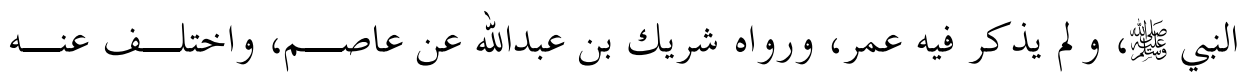

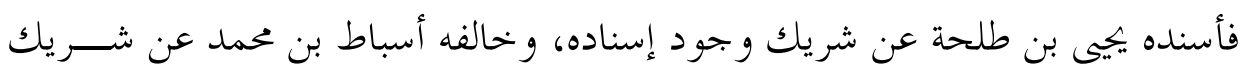
فلم يذكر في الإسناد عامراً. وقال عثمان بن أبي شيبة عن شريك عن عاصم عن عبدالا لله بن عامر عن أبيه عــنـ

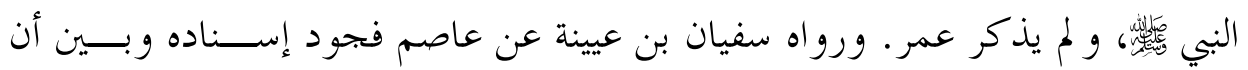

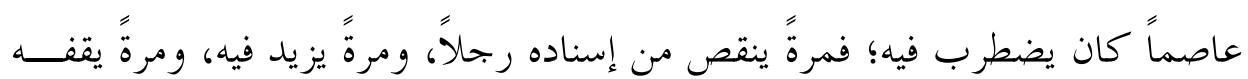


على عُمر، وقال ابن عيينة: وأكثر ذلك كان يقوله عن عبدالله بن عامر عن أبيه عــنـ

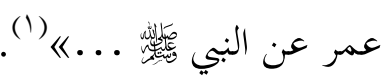

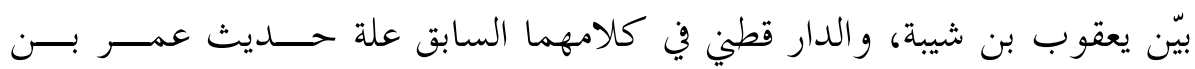

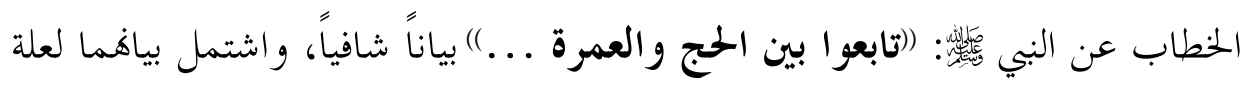

$$
\text { ا الحديث على عدة خطوات مرتبة. }
$$

بدأ يعقوب بذكر الراوي الذي تلتقي عنده الأسانيد وهو مدار الحديث وذكر اسمه

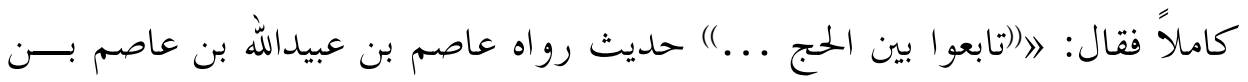
عمر بن الخطاب《، وبنحوه قول الدارقطني. فالخطوة الأولى تحديد الراوي مدار الحديث من حيث اسمه ونسبه ومولده ووفاتسـهـ

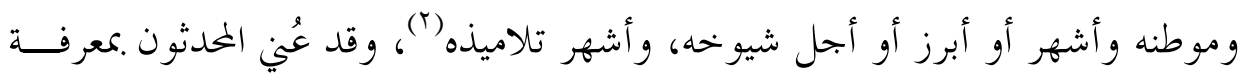
الرجال من جميع النواحي المتقدمة؛ فمن الناحية الاسمية عنوا بإزالة الإهـام وتعيين أسماء

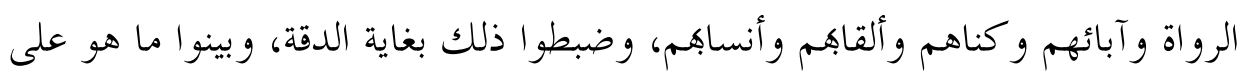

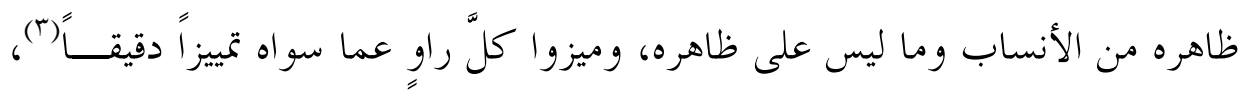

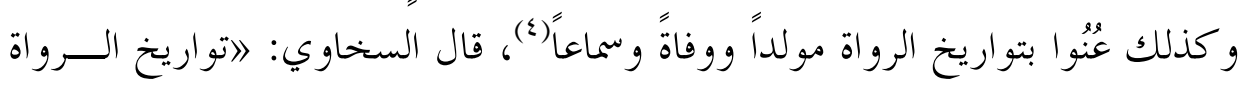
والوفيات ... وهو فن عظيم الوقع من الدين، قديم النفع به للمســلمين، لا يســتغنى

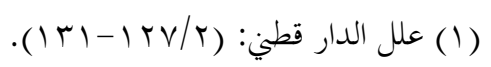

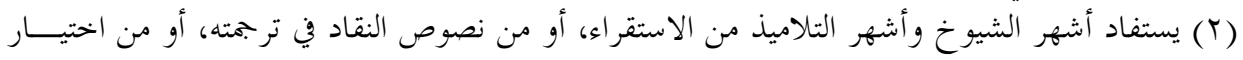

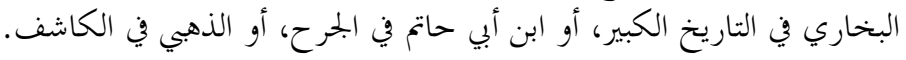

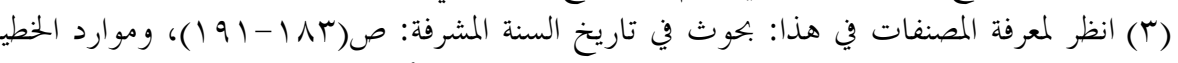

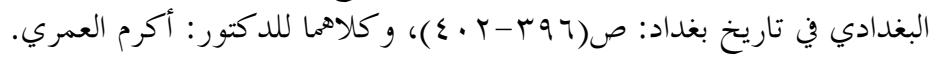
(ع) انظر لمعرفة المصنفات في هذا المرجعين السابقين. 
عنه . (1) (1) (

وللمتقدمين أقوال كثيرة دقيقة دالة على مدى اهتمامهم هذذا الجحانب مــن علـــوم

الحديث؛ فمن تلك الأقوال: قول سفيان الثوري: 》الما استعمل الرواة الكذب، استعملنا

هم التاريخن

وقول حفص بن غياث: 》إذا اتمتم الشيخ فحاسبوه بالسنينه"(r)، وقول حسان بن

زيد: 》الم نستعن على الكذابين بمثل التاريخ، نقول للشيخ: سنة كم ولدت؟ فإذا أقــر

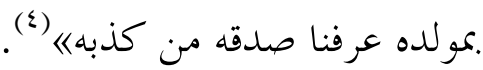

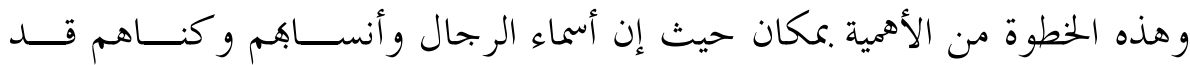

تتشابه، مما يوقع الباحث في أوهام كبيرة. قال المعلميّ -رحمه الله-: الأسماء كثيراً ما تشتبه ويقع الغلط والمغالطة فيها ... وقد يقول المحدث كلمة في راوٍ فيظنها السامع في آخر، ويمكيها كذلك وقد يجكيها السامع فيمن قيلت فيه ويخطئ بعض مــن بعــــه فيحملها على آخر؛ ففي الرواة المغيرة بن عبد الرحمن بن الحارث بن هشام المخزومي،

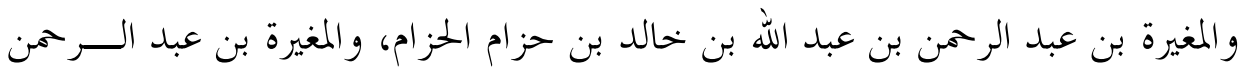

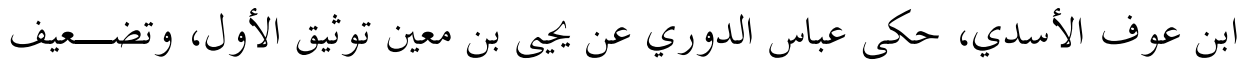

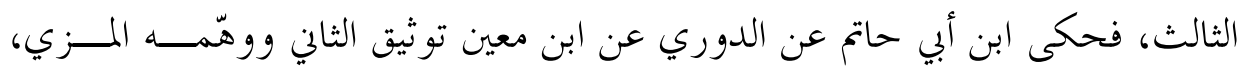
ووثق أبو داود الثالث وضعف الأول، فذكرت له حكاية الدوري عن ابن معين فقال: غلط عباس، ويي الرواة محمد بن ثابت العبدي وغيرهما .... وفي الرواة عمر بن نــافع مولى ابن عمر، وعمر بن نافع الثقفي ..."

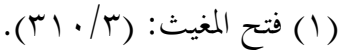

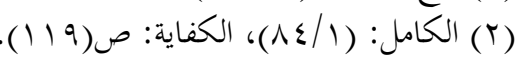

$$
\begin{aligned}
& \text { (צ) (ب) الكفاية: ص(1) (1) (1). }
\end{aligned}
$$

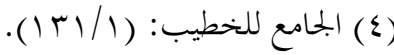

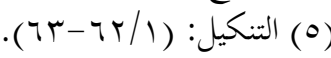




\section{ولا بدّ هنا من التنبيه إلى:}

1- عدم التوسع في هذه الخطوة بحيث تخرج عن مقصودها الأصلي وهو التعريف

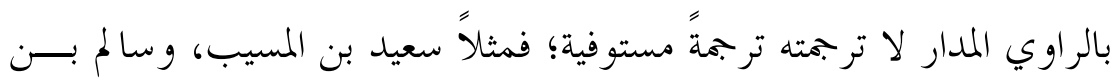

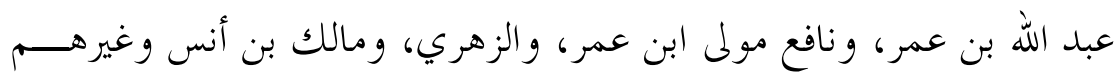

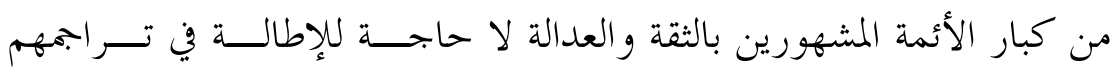
لشهرهم بل يكتفى بتعريف مختصر. r- العناية بالرجوع إلى المصادر الأصلية المتقدمة التي عُنيت هذذا الجحانب: كتاريخي البخاري الكبير، والأوسط، والجرح و التعديل، وغيرها- قدر الإمكـــان؛ لأن

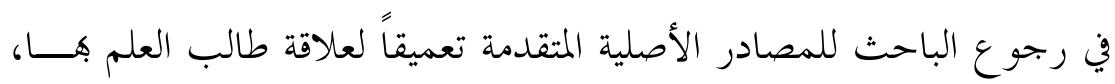

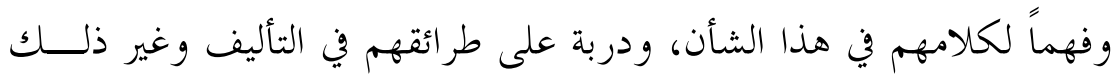
من الفوائد.

\section{r- بيان حال الراوي الذي تلتقي عنده الأسانيد:}

بعد تحديد المدار بين يعقوب بن شيبة حال المدار من حيث القوة والضعف فقـــال: 》وهو مضطرب الحديث《،، وقال الدار قطني: او لم يكن بالحافظ《.

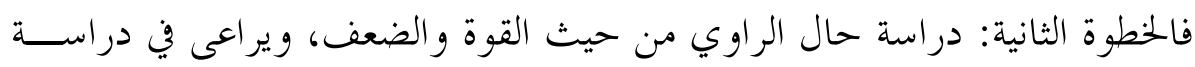

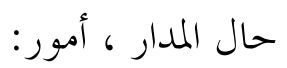
- - - مل هل هو ثقة أو ضعيف أم فيه تفصيل؟

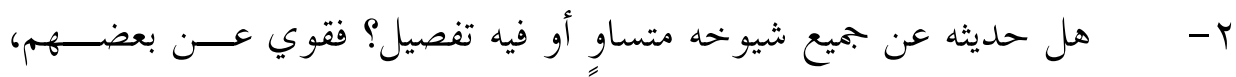
وضعيف عن البعض الآخر.

r- - مل حلديث تلاميذه عنه متساوٍ أو فيه تفصيل؟ فبعضهم أقوى من بعض.

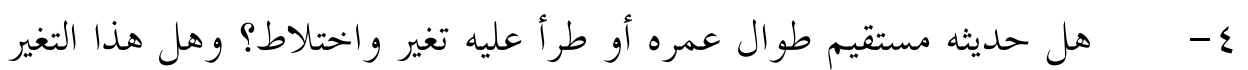


ضار أم غير ضار؟ وهل حدّث بعد التغير أم لا؟ وهل ظهرت له مناكير بعد التغيير أم لا؟ و لا بد من تحديد مبدأ التغير والاختلاط بدقة. 0 - مل حلديثه في جميع الأماكن متساوٍٍ أو فيه تفصيل؟ وسبب ذلك.

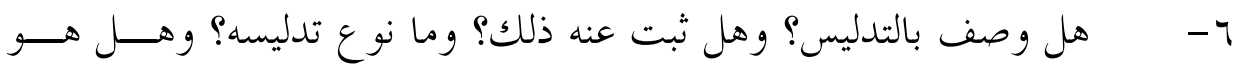
مكثر منه أم مقل؟ وهل تدليسه عام في شيوخه أو خاص ببعض الشــيوخ؟ وهل يدلس عن الثقات فقط أو عن الثقات و الضعفاء؟ وكيفية تعامل الأئمة مع حديثه المدلس. -V هل هو يرسل عن شيو خه؟ وهل ثبت عنه ذلك؟ فإن ثبت أنه يرسل ينظر في ثبوت سماعه من شيوخه؟ ويعتنى بكام الإمام البخاري في تاريخـــه الكـــبير

$$
\text { و الأوسط وتصرفاته في الصحيح. }
$$

وللشيخ عبد الرحمن المعلمي - رحمه الله- كلام نفيس في كيفية البحث عن أحوال الرواة في كتب الجرح و التعديل في كتابه القيم "التنكيل" ولعلي أذكره باختصار خشية الإطالة، وإن كانت جديرة بأن تذكر كاملة بحروفها، قال: المن أحب أن ينظر في كتب الجرح و التعديل للبحث عن حال رجال وقع في سندٍ

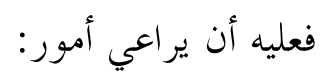
الأول: إذا وجد ترجمة بمثل ذاك الاسم فليثبت حتى يتحقق أن تلك الترجمة هـي

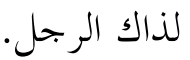

الثاني: ليستوثق من صحة النسخة وليراجع غيرها إن تيسر له ليتحقق أن ما فيهـــا ثنابت عن مؤلف الكتاب. الثالث: إذا وجد في الترجمة كلمة جرح أو تعديل منسوب إلى بعض الأئمة فلينظر أثنابتة هي عن ذاك الإمام أم لا؟ 
الرابع: ليستثبت أن تلك الكلمة قيلت في صاحب الترجمة فإن الأسماء تتشابه.

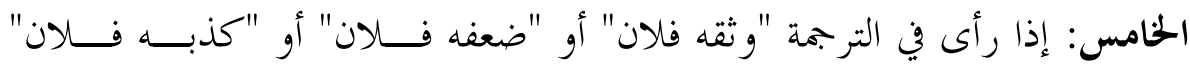

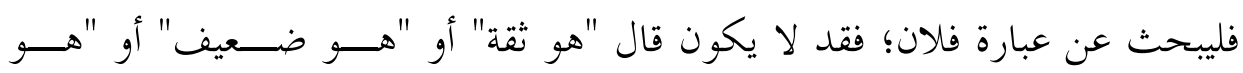

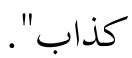

السادس: أصحاب الكتب كثيراً ما يتصرفون في عبارات الأئمة بقصد الاختصــار أو غيره، ور.ما يخل ذلك بالمعنى.

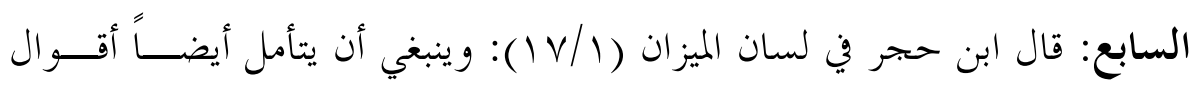

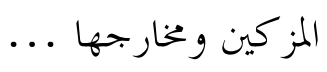

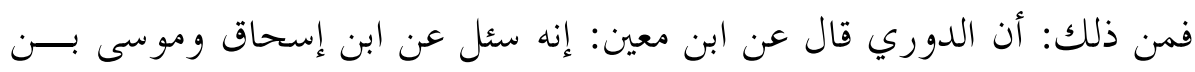

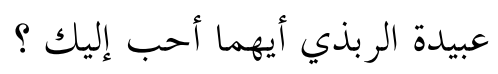

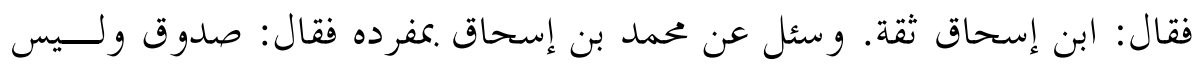

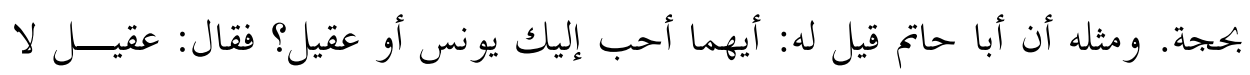

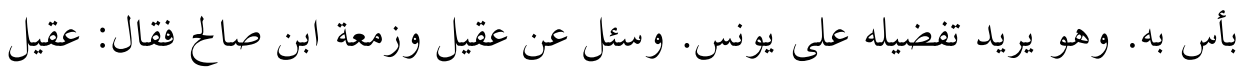

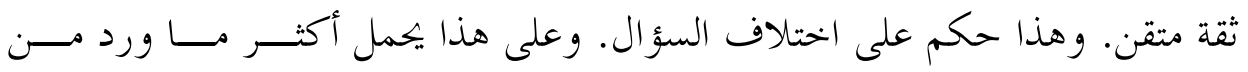

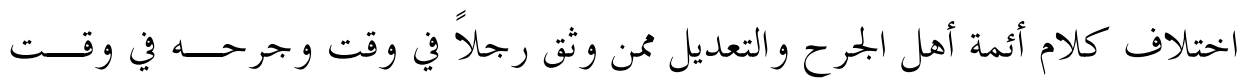
آخر. الثامن: ينبغي أن يبحث عن معرفة الجارح أو المعدل بمن جرحه أو عدله.

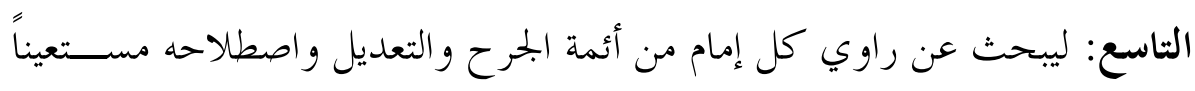

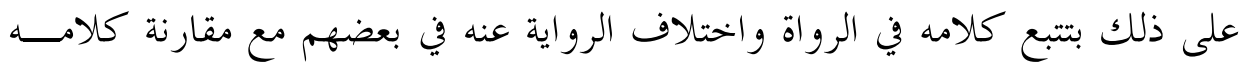
بكلام غيره. - مان. 
العاشر : إذا جاء في الراوي جرح وتعديل فينبغي البحث عن ذات(') بين الـــراوي

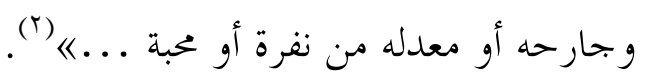

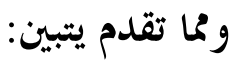

أ) أن دراسة حال الراوي ليست بالأمر الهيّن - كما يظن البعض- بل بل ربما راجــع

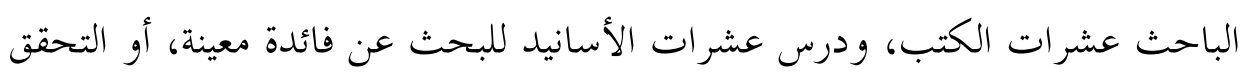

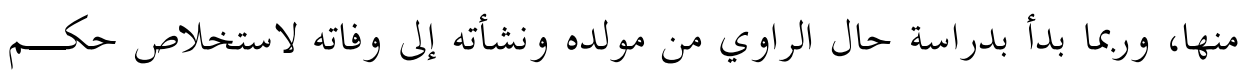
دقيق لحاله، و تأمل حال السلف في هذا الباب.

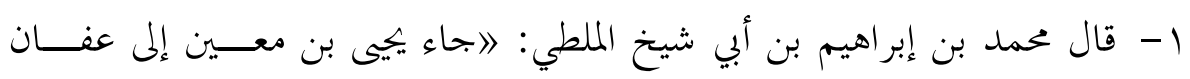

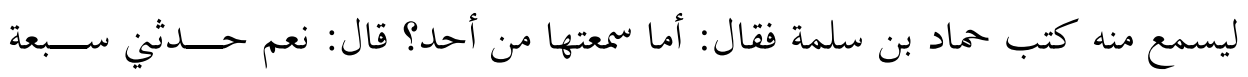

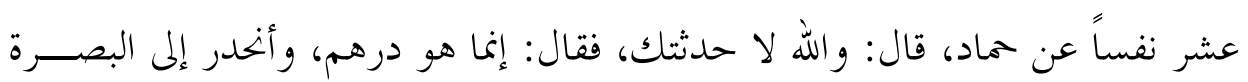

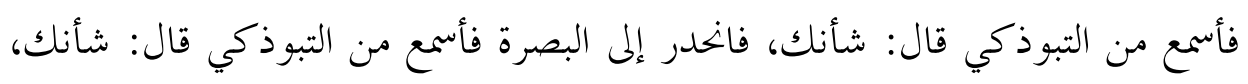

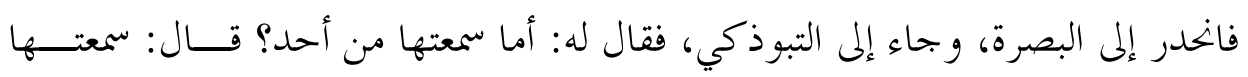

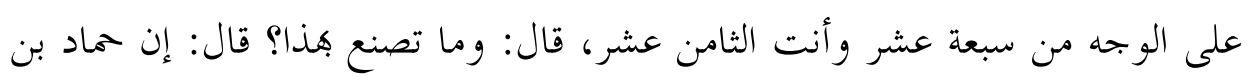

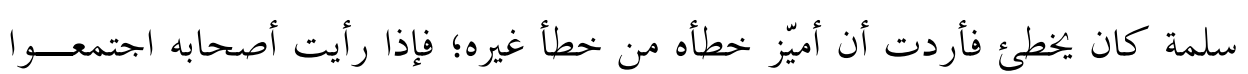

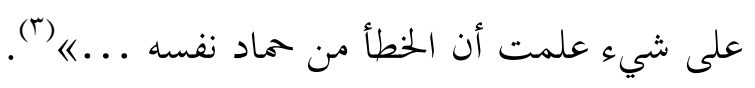

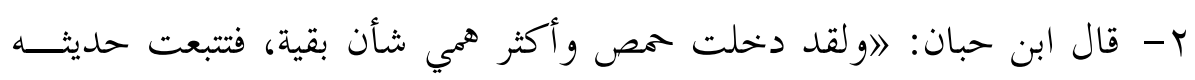

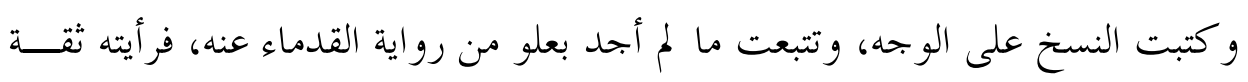

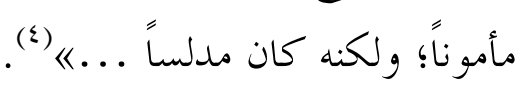

(1) كذا وقع، ويبدو أن في الكلام سقطاً، والله أعلم. (1) (1) (1) (1)

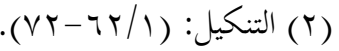

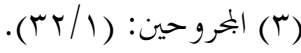

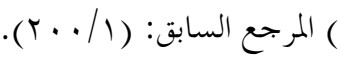


ب) أنّ من يعتمد على الكتب المتأخرة فقط دون الرجوع إلى المصــادر الأصـلية المتقدمة من تواريخ وسؤ الات وعلل وغيرها، قد قصّر ور.بما فاته الشيء الكثير عن هذا الراوي المعين، و الله المستعان.

\section{ب- ذكر الرواة عن المدار وبيان اختلافهم عنه:}

بعد تحديد المدار، وبيان درجته في الرواية ذكر يعقوب بن شيبة الرواة عن المـــدار

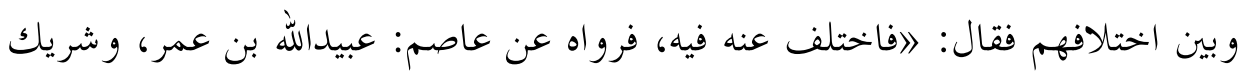

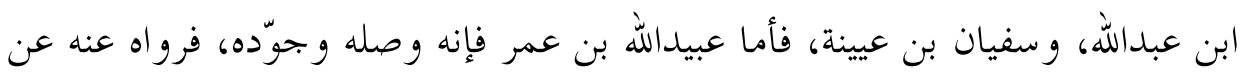

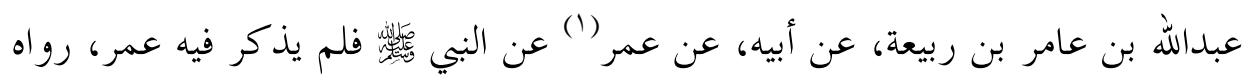
مرة أخرى عن عمر عن النبي ئس

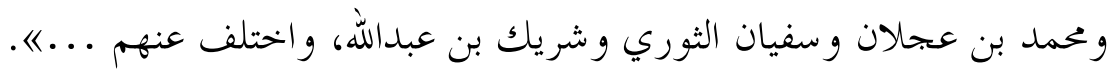

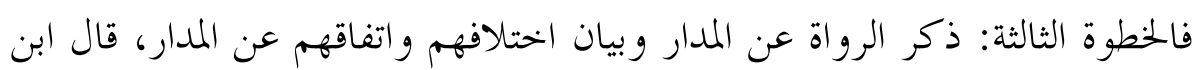

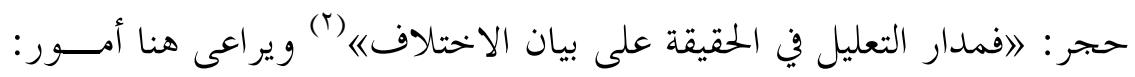

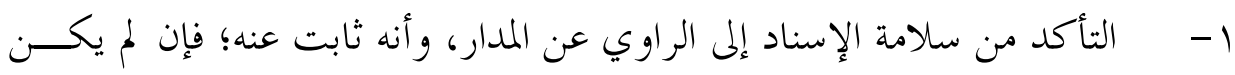
ثابتاً فلا يعتمد عليه و لا يذكر إلاّ من باب التادي التنبيه عليه.

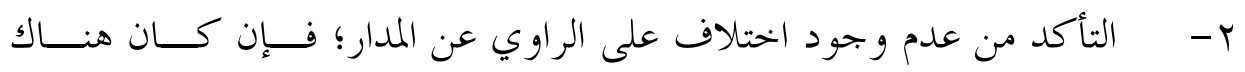
اختلاف يدرس للتحقق من الرواية الراجحة.

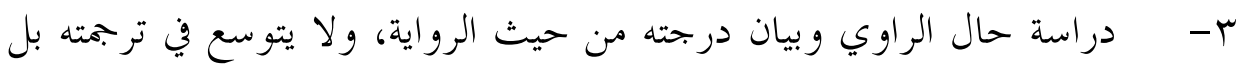
يذكر ما يفي بالغرض.

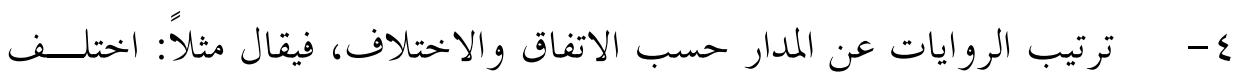
عن الزهري على خمسة أوجه: 
الأول: رواه فلان، وفلان - في الراجح عنه- عن الزهري ... يذكر الوجه.

الثاني: رواه فلان، وفلان - في الراجع عنه- عن الزهري ... يذكر الوجــه.

وهذا" (1)

ع - الموازنة بين الروايات وبيان الراجح وأسباب الترجيح:

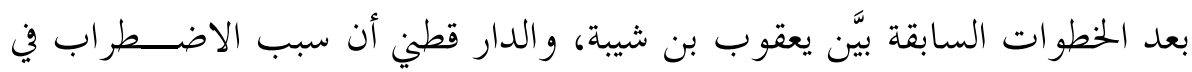

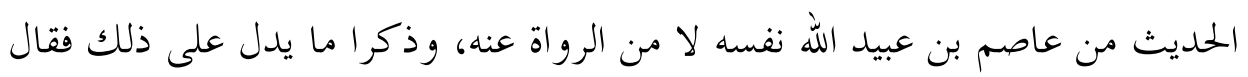
يعقوب: او لا نرى هذا الاضطراب إلى من عاصم، وقد بين ابن عيينة ذلك في حديثه

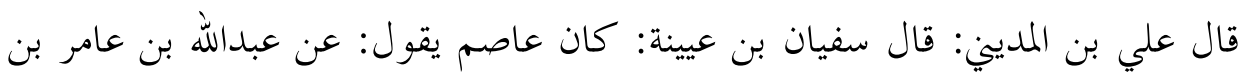

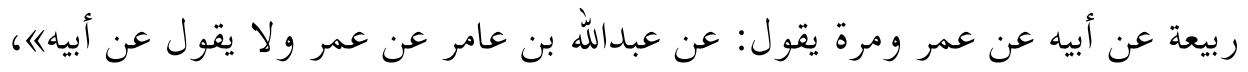
وقال الدار قطي: لاورواه سفيان بن عيينة عن عاصم فجود إسناده وبين أن عاصــمـاً

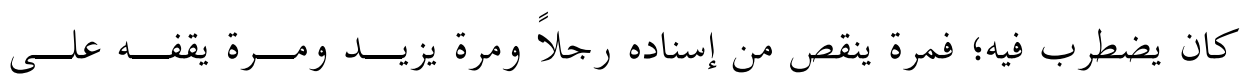
عمر ..."

إذاً الخطوة الرابعة الموازنة بين الروايات وبيان الراجح وأسباب الترجيح؛ وهذه من

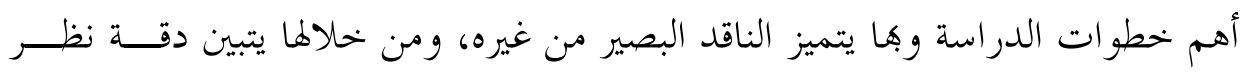

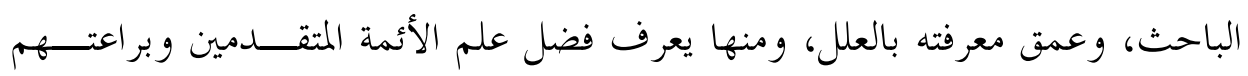

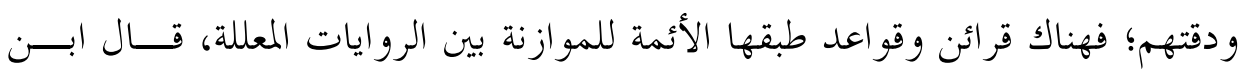

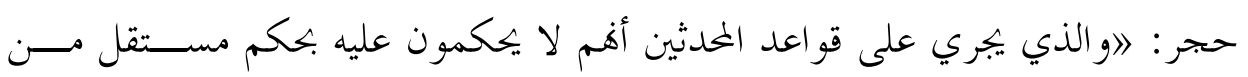

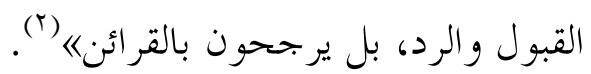

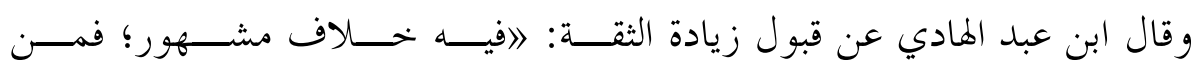

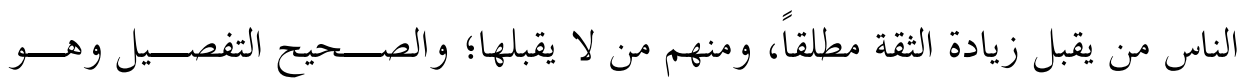




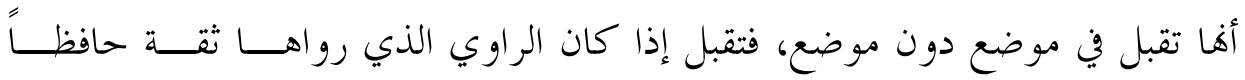

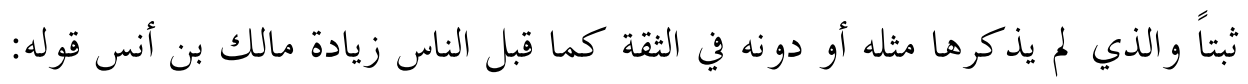
((من المسلمين) في صدقة الفطر، واحتج هـا أكثر العلماء، وتقبل في موضع آخر لقرائن تخصها، ومن حكم في ذلك حكماً عاماً فقد غلط، بل كل زيادة ها حكم يخصـــها؛ ففي موضع يجزم بحصتها.. وفي موضع يغلب على الظن صحتها... وفي موضع يجــزم

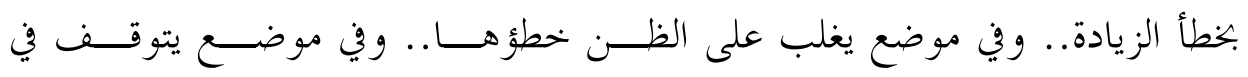
الزيادة《) (1)

وقال العلائي -رحمه الله-: اوأما أئمة الحديث، فالمتقدمون منهم كيحى بن سعيد

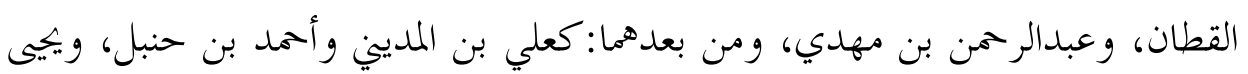

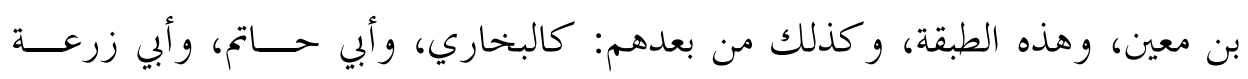

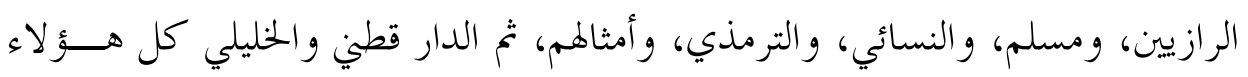

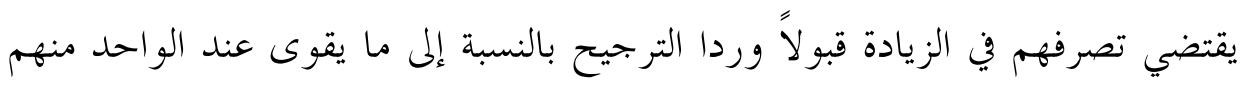

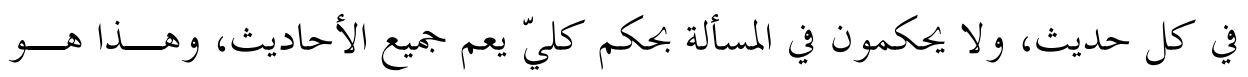
الحق الصواب كما سنبينه إن شاء الله تعالىه) (r).

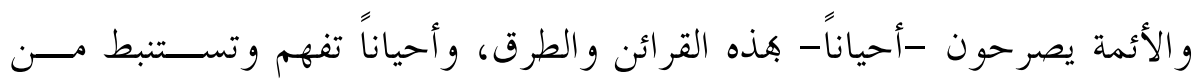
صنيعهم، فمن تلك الطرق و القرائن (ॅ)

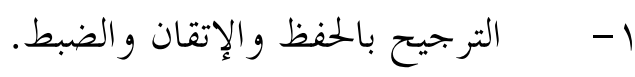
r - الترجيح و العلد و الكثرة.

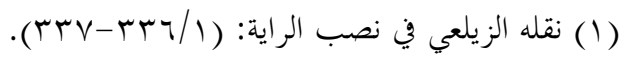

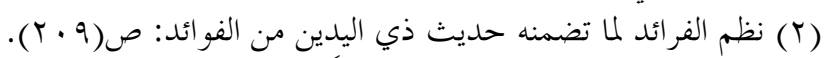

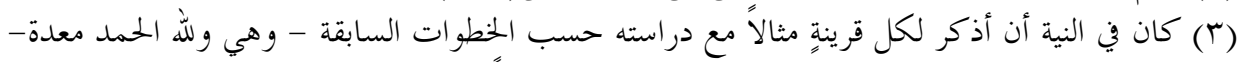

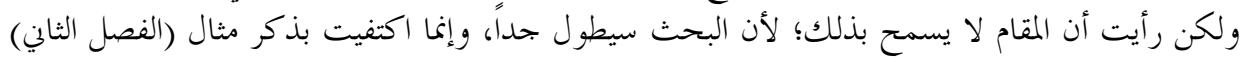
فيه مراعاة لبعض هذه القر ائن. 
r- سلوكك الراوي للجادة والطريق المشهورة. ع - الترجيح بالنظر إلى أصحاب الراوي المقدمين فيه. - - - م الترجيح باعتبار البلدان واتفاقها.

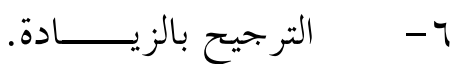
عدم وجود الحديث في كتب الراوي الذي روي الحديث عنه. -1 - شهرة الحديث و انتشاره من طريق يدل على غلط من رواه من طريق آخر. 9- وجود قصة في الخبر تدل على صحة الطريق. . - التفرد عن إمام مشهور وله تلاميذه كثيرون. 11 - تحديث الراوي في مكان ليس معه كتبه. r ا I - التحديث بنــزول مع إمكانية العلو في السماع. rا - عدم العلم برواية الراوي عمن روى عنه، أو عدم سماعه منه. ع إ- إمكانية الجمع بين الروايات عند التساوي. 10- - إية الراوي عن أهل بيته. 17 - اختلاف البحالس وأوقات السماع.

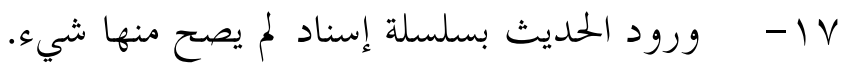
11 - إل - التحديث من كتاب. - - - معف الراوي أو وهمه أو اضطرابه. • - r مشابهة الحديث لحديث راوٍ ضعيف.

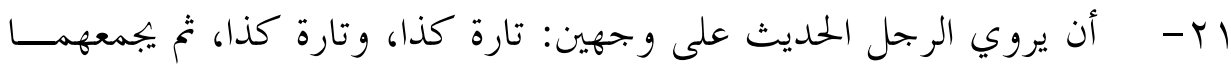
معاً؛ فهذا قرينة على صحتها معاً.

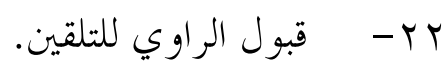
rr- - ورود الحديث عن راوٍٍ وقد ورد عنه ما يدل على خلافه موقوفاً. 
ع - - مخالفة الراوي لما روى سواء وجد اختلاف أو لم يوجد - على تفصــيل في ذلك-.

$$
\begin{aligned}
& \text { هr- اضطراب إحدى الروايــات. } \\
& \text { بr- - دلالة الرواية على الكـــــب. }
\end{aligned}
$$

- HV

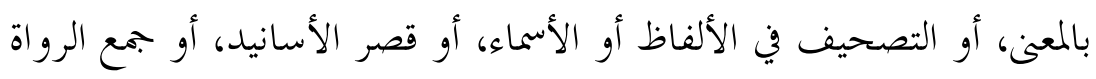

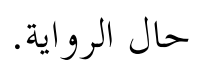

والحق أن قرائن الترجيح كثيرة لا تنحصر؛ فكل حديثٍ له نقد خحاص. قال ابن حجر : اووجوه الترجيح كثيرة لا تنحصر ولا ضابط ها بالنسبة إلى جميع الأحاديث، بل كل حديث يقوم به ترجيح خاص، وإنما ينهض بذلك الممارس الفطــنـ

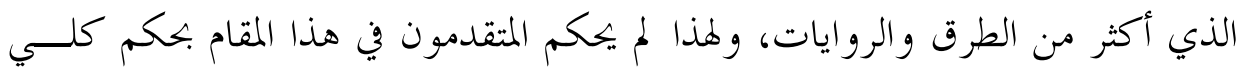
يشمل القاعدة بل يختلف نظرهم بكسب ما يقوم عندهم في كل حديث بمفرده (1).

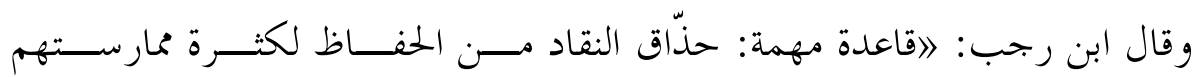
للحديث، ومعرفتهم بالرجال، وأحاديث كل واحد منهم، لهم فهم خاص يفهمون به رهم أن هذا الحديث يشبه حديث فلان، و لا يشبه حديث فلان، فيعللون الأحاديث بذلك، وهذا مما لا يعبر عنه بعبارة تحصره، وإنما يرجع فيه إلى بحرد الفهم والمعرفة التي خصوا

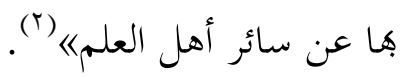
هذا ما استطعت أن أجمعه في هذا الموضوع، وهو جهد المقل، ولكن أســأل الله أن يبارك فيه.. إنه سميع بحيب. 


\section{الفصل الثاني \\ الجانب العملي أو التطبيقي}

وهو عبارة عن دراسة مثال لحديث معل مختار من علل الدارقطني، ودراسته دراسة مستفيضة على ضوء الخطوات التي ذكرةا في المبحث الثاني من الفصل الأول، والذي كان يغلب عليه الجحانب النظري.. و إليك المثال:

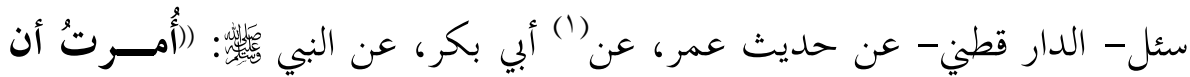
أقاتل الناس حتى يقولوا لا إله إلا الله) الحديث ؟ فقال: - م هو حديث يرويه الزهري، واختلف عنه: فممن رواه على الصواب: شعيب بن أبي حمزة، ويهيى بن سعيد الأنصاري، ومحمد

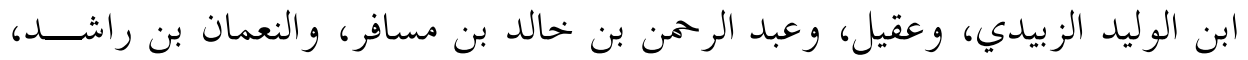

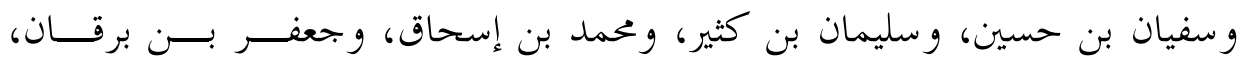
وعبدالرحمن بن يزيد بن تميم.

فرووه عن الزهري، عن عبيد الله بن عبد الله بن عتبة، عن أبي هريرة، قال: قـــال عمر لأبي بكر. واختلف عن سفيان بن حسين:

فأسنده عنه محمد بن يزيد الواسطي، عن الزهري، عن عبيد الله، عن أبي هريرة(؟). وأرسله يزيد بن هارون، فأسقط منه "أبا هريرة" (ب).

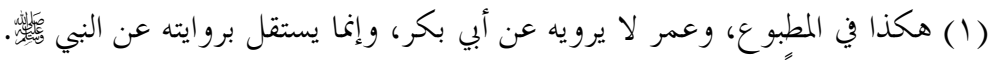

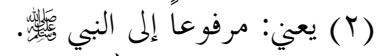

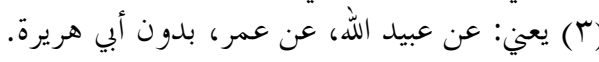


ورو اه معمر بن راشد، واختلف عنه:

فأسنده رباح بن زيد، عن معمر، عن الزهري، عن عبيد الله، عن أبي هريرة .متابعة من تقدم حديثه.

وأرسله عبد الرزاق ؛ عن معمر، عن الزهري، عن عبيد الله لم يذكر أبا هريرة. ورواه عمران القطان عن معمر، وقال: عن الزهري، عن أنس بن مالك عــن أبي بكر، وووهم فيه على معمر.

وروواه “ييى بن أبي أنيسة، عن الزهري، عن سعيد بن المسيب، عن أبي هريرة، عــن الني وروواه صالح بن أبي الأخضر، فقال: عن الزهري، عن سعيد وأبي سلمة، عــن أبي

ورواه الوليد بن مسلم، عن شعيب، ومرزوق بن أبي الهذيل، وسفيان بن عيينة، عن الزهري، عن سعيد، عن أبي هريرة.

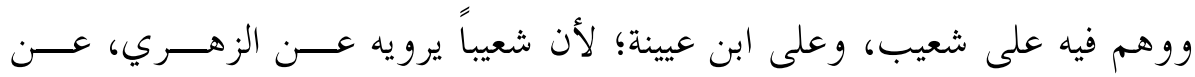
عبيدالله، عن أبي هريرة(1).

وابن عيينة يرويه عن الزهري مرسلًا لا يذكر فوقه(r) أحداً (r)". انتهى ما قاله الدار قطين في مسند أبي بكر. ثم سئل مرة أخرى عن هذا الحمديث في مسند أبي هريرة. فقال: يرويـــه الزهـــــي، واختلف عنه:

فرواه يجيى بن سعيد الأنصاري، وابن أبي عتيق، ويونس بن يزيد، و شعيب بــن أبي 


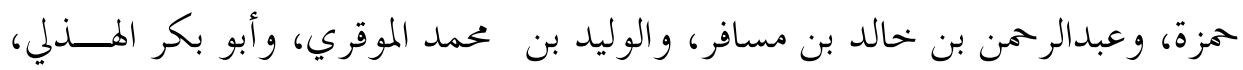
عن الزهري، عن سعيد بن المسيب، عن أبي هريرة(').

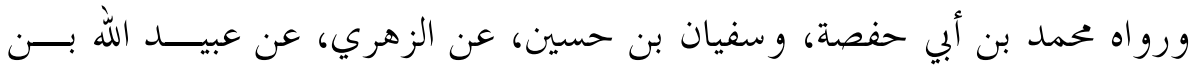

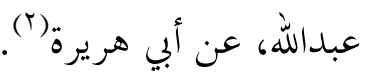
ورواه سليمان بن أبي داود الحراني، عن الزهري، عن عبيد الله بن عمير، عــن أبي هريرة. وحديث سعيد بن المسيب هو الصحيح. وحديث عبيد الله بن عبد الله أيضاً (r). وحدث به النضر بن شثيل، عن صالح بن أبي الأخضر، عن الزهري، عــن سـعيد وأبي سلمة، عن أبي هريرة. ولا يثبت فيه ذكر أبي سلمة (ع) انتهى كلام الده الدار قطني. تخزيج الحديث: هذا الحديث مداره على الزهري، واختلف عليه من ثمانية أوجه:

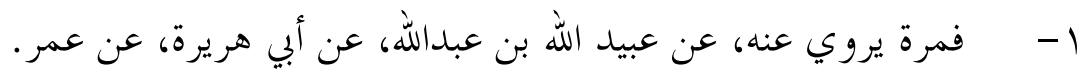
r- - مورة يروي عنه، عن عبيد الله بن عبدالله، عن عمر بدون ذكر أبي هريرة. r- - م ومرة يروي عنه، عن عبيد الله بن عبدالله، عن أبي هريرة - بلدون عمر.

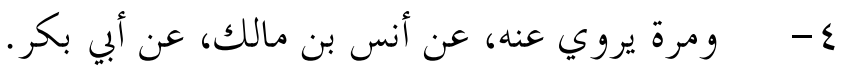
ه - ومرة يروي عنه، عن سعيد بن المسيب، عن أبي هريرة.

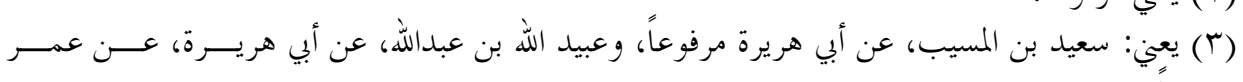




$$
\begin{aligned}
& \text { 7- ومرة يروي عنه، عن سعيد بن المسيب وأبي سلمة، عن أبي هريرة. } \\
& \text { - م ومرة يروي عنه، عن عمر بن الخطاب - لا يذكر بينه وبينه أحداً. } \\
& \text { 1 - م أهرة يروي عنه، عن عبيد بن عمير، عن أبي هريرة. }
\end{aligned}
$$

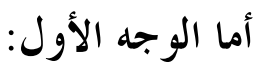

\section{(الزهري عن عبيدالله، عن أبي هريرة، عن عمر).}

فأخرجه البخاري في صحيحه - مع الفتح - كتاب: الاعتصام، بـــاب: الاقتـــداء

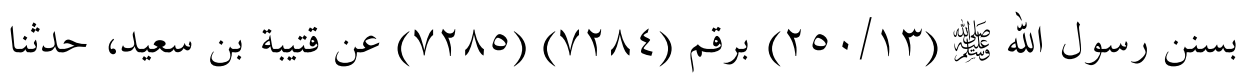

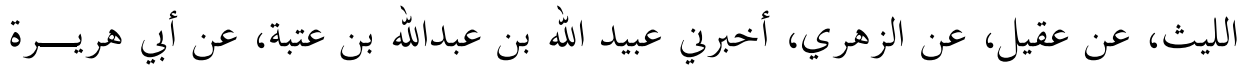

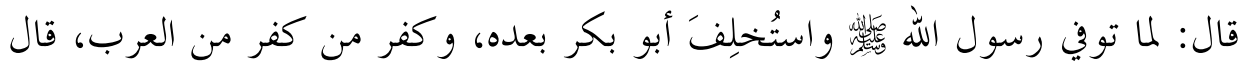
عمر لأبي بكر: كيف تقاتل الناس، وقد قال رسول الله بَّل حتى يقولوا لا إله إلا الله، فمن قال: لا إله إلا الله عصم مني ماله، ونفسه، إلا بحقه وحسابه على الله). فقال: و الله لأقاتلن من فرق بين الصلاة و الز كاة، فإن الز كاة حق المـــال، و الله لــــــ

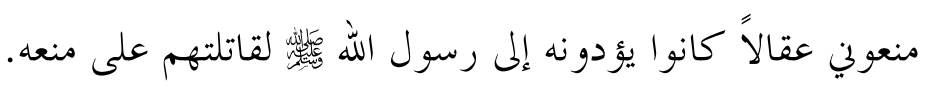
فقال عمر: فو الله ما هو إلا أن رأيت الله قد شرح صدر صدر أبي بكر للقتال فعرفت أنه أله الحق. ومسلم في صحيحه في كتاب: الإيمان، باب: الأمر بقتال الناس حتى يقولـــوال الا

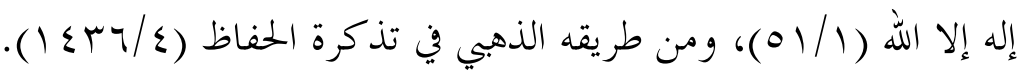

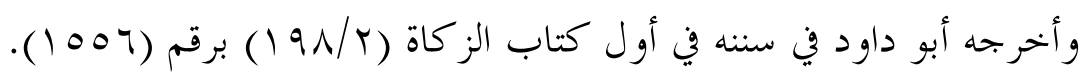
وقال: رواه رباح بن زيد ورو اه عبدالرزاق، عن معمر، عن الزهري بإسناده، وقال بعضهم ((عقالاً)). ورواه ابن وهب، عن يونس قال: "عناقاً". 
وقال أبو داود -أيضاً-: قال شعيب بن أبي حمزة، ومعمر، والزبيدي، عن الزهري، في هذا الحديث "لو منعوني عناقاً".

وروى عنبسة، عن يونس، عن الزهري في هذا الحديث قال: "عناقاً". و البيهقي في الكبرى (ع /ع • 1) من طريق أبي داود. ورواه الترمذي في جامعه في كتاب الإيمان، باب ما جاء "أمرت أن أقاتل النـــاس"

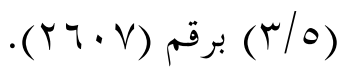

وقال: هذا حديث حسن صحيح، ثم قال: هكذا روى شعيب ابن أبي حمزة، عــن

$$
\text { الزهري، عن عبيد الله بن عبدالله، عن أبي هريرة. }
$$

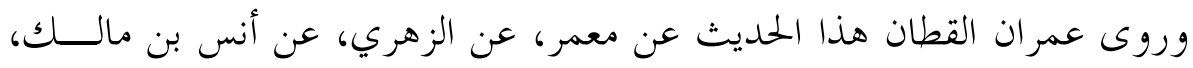

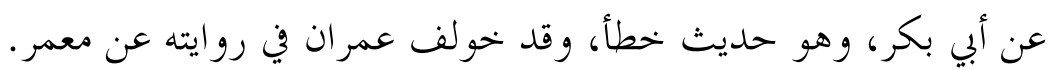
و النسائي في السنن الكبرى في كتاب الزكاة، باب قتال مانعي الز كاة (؟/N) برقم (TMT) و المحبى في كتاب الزكاة، باب مانع الزكاة (0/ • ())، وفي أول كتاب تحريم

$$
\text { الدم (V)/V) }
$$

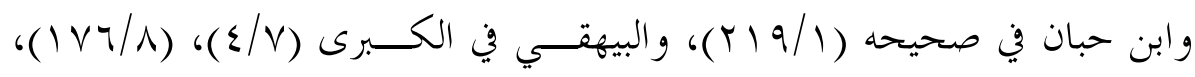

$$
\text { ( }
$$

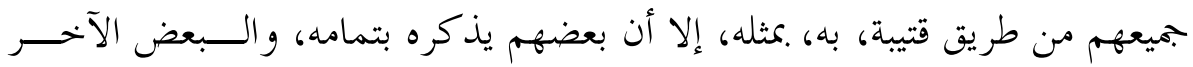

وقد تابع الليث بن سعد قتيبة بن مسلم في روايته الحديث عن عقيل:

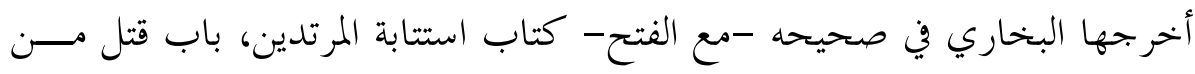

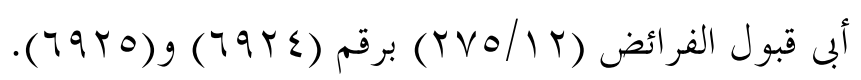

و البيهقي في معرفة السنن والآثار في كتاب قسم الصدقات، باب قسم الصـــدقات

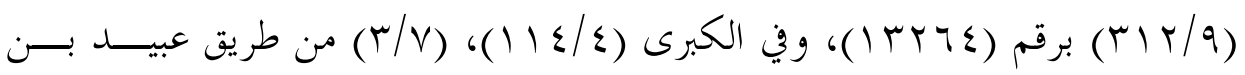


عبدالو احد، كلاهما عن يهيى بن بكير، عن الليث، عن عقيل، به، بنحوه.

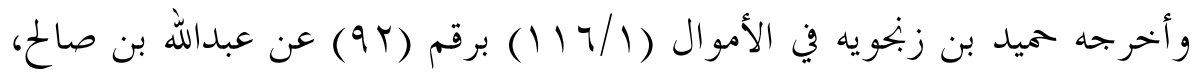
عن الليث، به، مختصراً. وعلق البخاري هاتين الروايتين لكل من (يهيى بن بكير، وعبدالله بن صالح) عقـــب

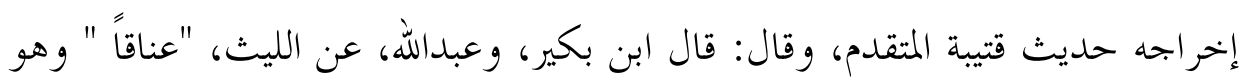
أصح (يعني من رواية "عقالاً" ورواية الإهمام "كذا و كذا" دون تحديد) (1) . وذكر ابن المديني الحديث، وأشار إلى رواية عقيل هذه في العلل (ص • م) فقـــال: رواه صالح، عن ابن شهاب، عن ابن المسيب، عن أبي هريرة.

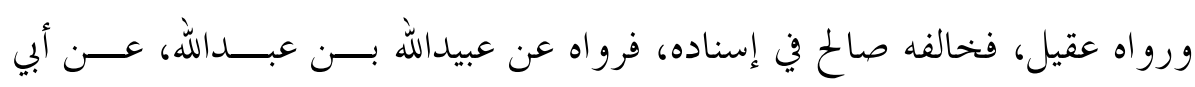
هريرة، عن عمر بن الخطاب. ورو اه معمر، عن الزهري، عن عبدالله مرسلاً. ورواه سفيان بن حسين، عن الزهري، عن عبيدالله، عن أبي هريرة.

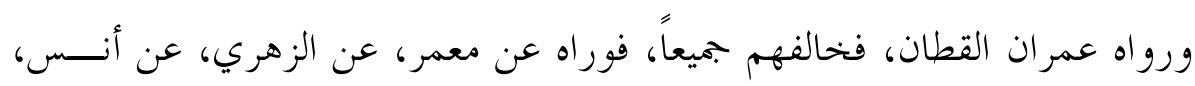
عن أبي بكر.

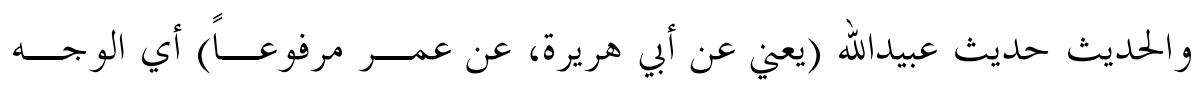

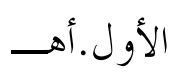

وقد تابع شعيب بن أبي حمزة، عقيلاً في رو ايته الحديث من هذا الوجه:

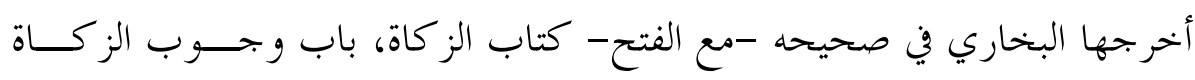

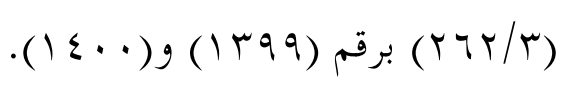

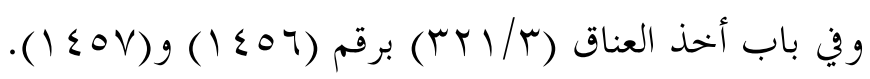

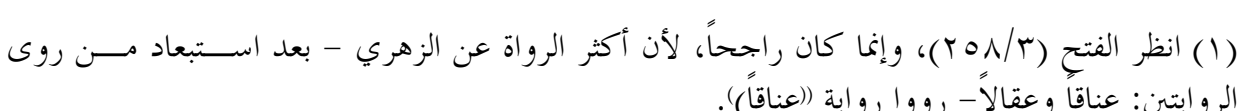




$$
\text { ومن طريقه: البغوي في شرح السنة (1/ }
$$

وأخرجه النسائي في السنن الكبرى في كتاب الجهاد، باب وجوب الجهـــاد (r/ه)

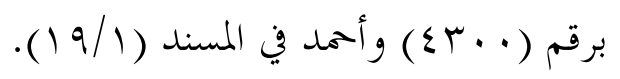

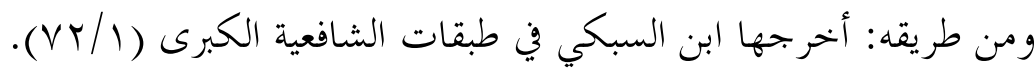

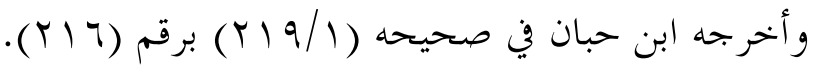

$$
\begin{aligned}
& \text { و البيهقي في الكبرى (ع/ع • (1). }
\end{aligned}
$$

جميعهم من طريق شعيب بن أبي حمزة، عن الزهري، به، بتمامه.

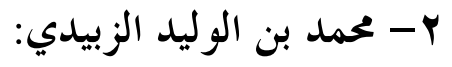

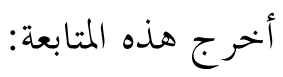

النسائي في السنن الكبرى في كتاب الجهاد، باب وجوب الجهرــاد (س/ع) بـــرقم

$$
\text { والبحتى في أول كتاب الجهاد (7/7). }
$$

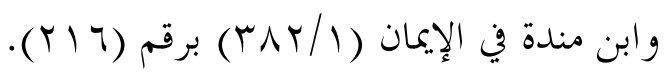

كالاهما من طريق محمد بن حرب، عن الزبيدي، عن الزهري، به، بنحوه. وقال ابن منده: هذا إسناد بحمع على صحته، رواه ابن سالم عن الزبيدي. وروى هذا الحمديث عن الزهري: يهيى بن سعيد، ويونس بن يزيد الأيلي، وسليمان

$$
\text { بن كثير، ومحمد بن أبي حفصة. }
$$

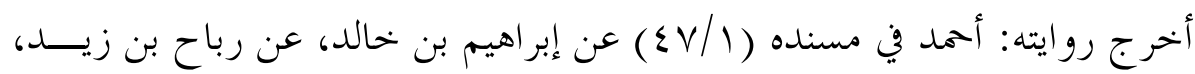

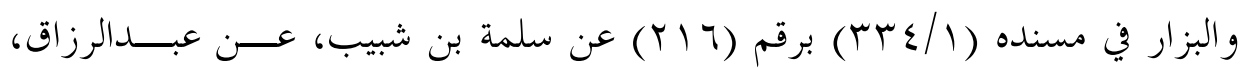

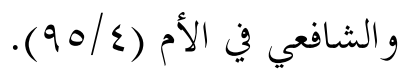




\section{والمسند -بترتيب السندي- (1/ ع 1 ) عن الثقة(1).}

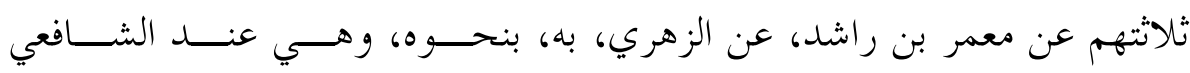

باختصار.

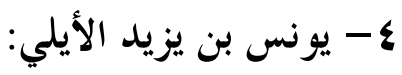

أخرجها أبو داود في سننه في أول كتاب الزكاة (r/ . . r) برقم (100V) عن ابن السرح (هو أحمد بن عمرو)، و سليمان بن داود، قالا: أخبرنا ابن وهــب، أخسبرلي يونس، عن الزهري، وأحال إسناده ومتنه على حديث عقيل.

\section{ه- النعمان راشد:}

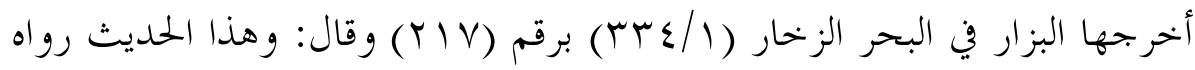

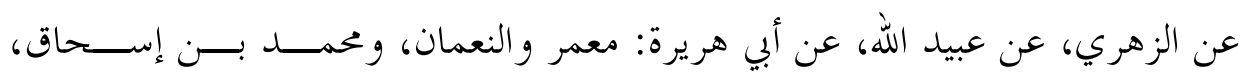
وإبراهيم بن سعد، وغيرهم، فاجتْزَينا بمعمر، وقال صالح بن أبي الأخضر: عن الزهري،

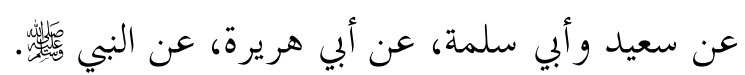
צ- عبدالرحن بن خالد بن مسافر:

أخرجها البخاري في صحيحه - مع الفتح - كتاب الزكاة، باب أخذ العنــاق في

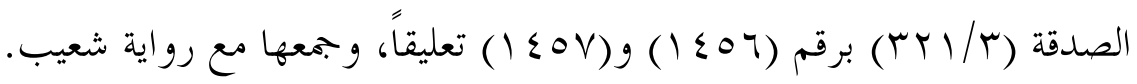
وذكر ابن حجر أن الذهلي وصلها في كتابه "الزهريات" عن عبدالله بن صالح، ثنا الليث، به، (أي: عن عبدالرحمن بن خالد). (تغليق التعليق (r/ • ب)).

(1) قال البيهقي: وقد قال الشافعي: أخبرنا الثقة، عن معمر، والمراد به: إسماعيل بن عُلْيّة لتسميته إيـاه في

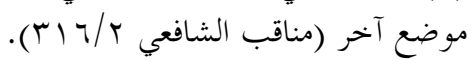

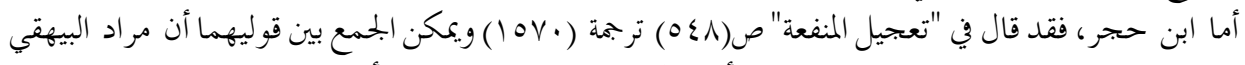

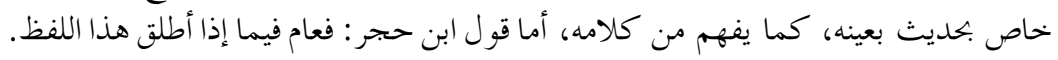




$$
\begin{aligned}
& \text { - Vيى بن سعيد. } \\
& \text { 1- محمد بن إسحاق. } \\
& 9 \text { - سفيان بن حسين. } \\
& \text { • } 1 \text { - جعفر بن برقان. } \\
& \text { | } 1 \text { - عبد الرحن بن يزيد بن تميم. }
\end{aligned}
$$

وهم الرواة الذين ذكرهم الدارقطني في العلل - كما سبق - و لم أقف على رواياهم.

وقد تابع عقيلاً راو يان، لم يشر إليهما الدارقطي، وهمان

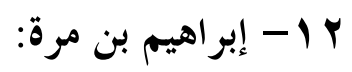

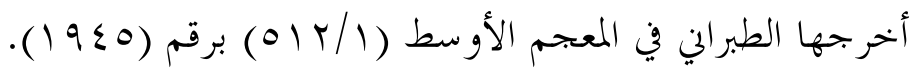

وفي مسند الشاميين (TV/1) برقم (Y (T))، عن أحمد بن مسعود، عن عمرو بن أبي سلمة، عن صدقة بن عبدالله، عن إبراهيم بن مرة، عن الزهري، به، بنحوه، وقال:

$$
\text { لم يروِ هذا الحديث عن إبر اهيم إلا صدقة. }
$$$$
\text { ب ا - الثقة عن ابن شهاب (سفيان بن عيينة): }
$$

أخرجها الشافعي في مسنده بترتيب السندي (1/ / 1) عن الثقة(1) عن ابن شهاب،

عن عبيدالله، عن أبي هريرة، أن عمر قال.... وذكره مختصراً.

ومن طريقه: البيهقي في معرفة السنن والآثار (T/M/I I I ).

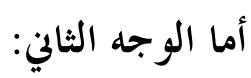

(الزهري، عن عبيد الله بن عبد الله، عن عمر بدون ذكر أبي هريرة)

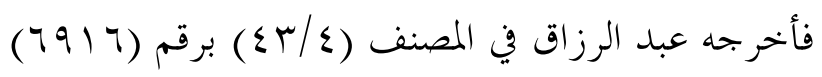

(1) قال البيهقي: وقد قال الشافعي: أخبرنا الثقة، عن معمر، والمراد به: إسماعيل بن عُليّة، لتسميته إياه في

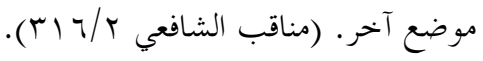




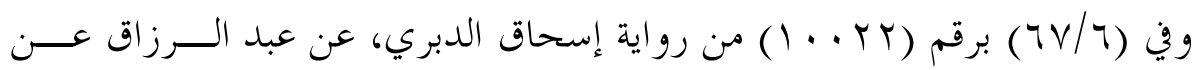

$$
\begin{aligned}
& \text { معمر، عن الزهري، به، بنحوه. }
\end{aligned}
$$

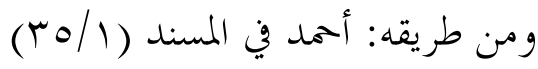

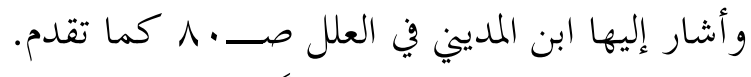

$$
\begin{aligned}
& \text { وقد تابع سفيان بن حسين معمراً: }
\end{aligned}
$$

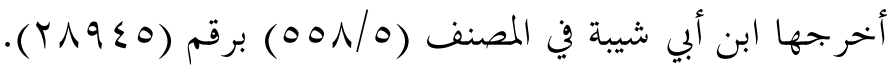

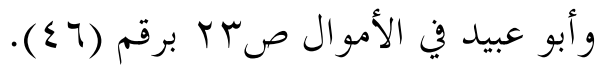

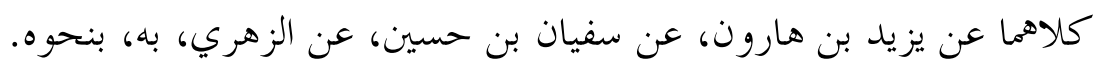

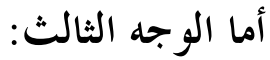

$$
\text { (الزهري، عن عبيد الله بن عبد الله، عن أبي هريرة، مرفوعاً). }
$$

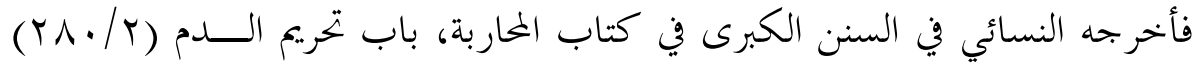

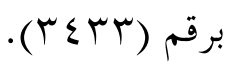

وفي المختى أول كتاب تحريم الدم (IV/V) (IV)، وقال: سفيان في الزهري ليس بالقوى،

$$
\text { وهو سفيان بن حسين. }
$$

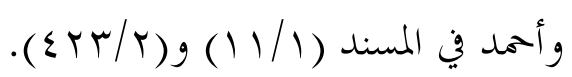

كلاهما عن محمد بن يزيد، عن سفيان بن حسين، عن الزهري، بها به، بنحوه.

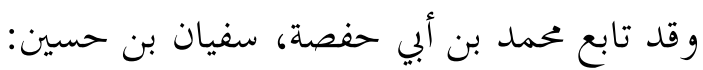

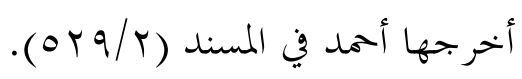

كما أشار إليها ابن المديني في العلل كما تماندا تقدم.

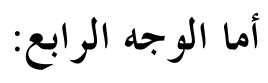

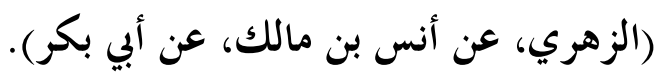

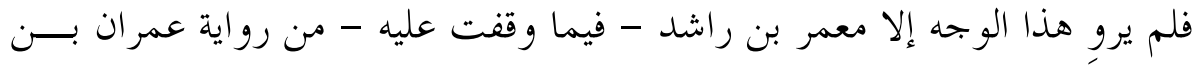

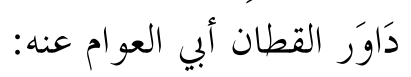




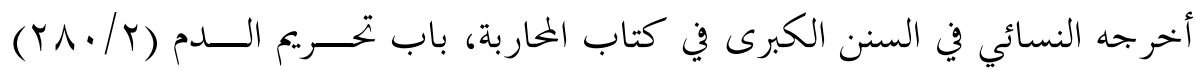

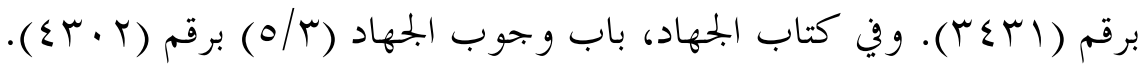

$$
\text { وفي البحتى أول كتاب الجهاد (7/7) وقال: }
$$

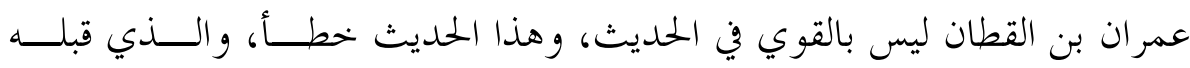
الصواب، حديث الزهري عن عبيد الله بن عبدالله بن عتبة، عن أبي هريرة.

$$
\begin{aligned}
& \text { وفي أول كتاب تحريم الدم (V/V• V). }
\end{aligned}
$$

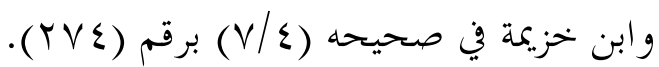

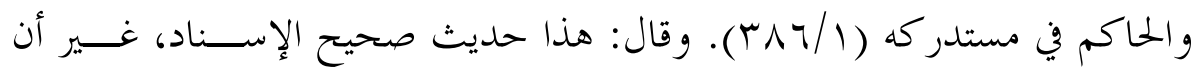
الشيخين لم يخرجا عمران القطان، وليس لمما حجة في تركه، فإنه مستقيم الحديث. وو افقه الذهبي في تلخيصه.

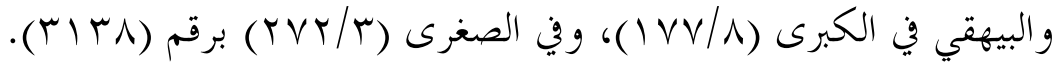

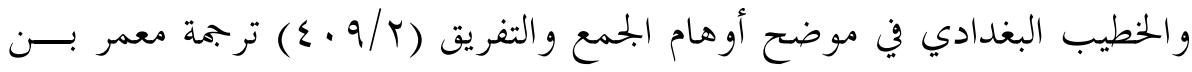
راشد، وقال: كذا قال عن الزهري. ورواه غيره عن معمر، عن الزهري، عن عبيد الله بن عبدا لله بن عتبــة، عــنـ أبي هريرة، وهو الصواب.

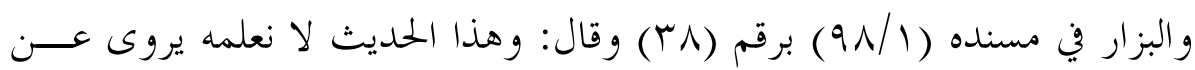
أنس، عن أبي بكر إلا من هذا الوجه، وأحسب أن عمـــــان أخططـأ في إســــاده؛ لأن

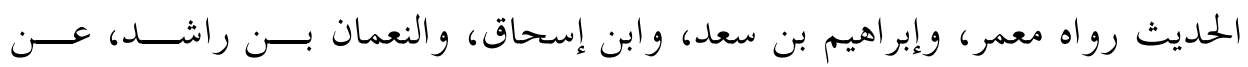

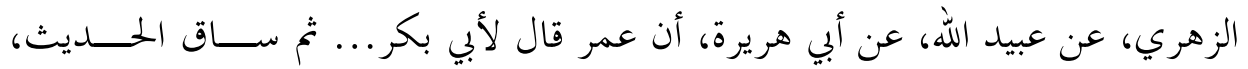
وقال في آخره:

فقلب عمران إسناد هذا الحلديث فجعله عن معمر، عن الزهري، عن أنس، عن أبي 
كما أخرجها ابن أبي حاتم في العلل من هذا الطريق في ثلاثة مواضع:

$$
\text { فني العلل (T/ }
$$

قال أبو حاتم، وأبو زرعة: هذا خطأ، إنما هو الزهري، عن عبيد الله بن عبد الله بن

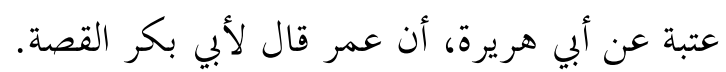

$$
\text { قلت لأبي زرعة: الوهم ممن هو؟ قال: هو من عمران. }
$$

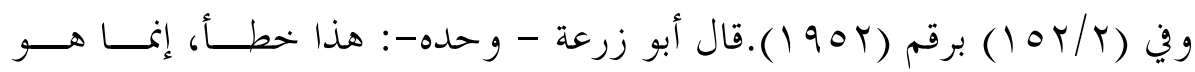

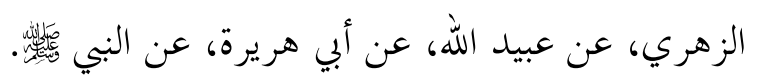

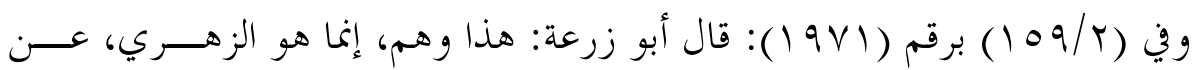

$$
\text { عبيد الله بن عبدالله، عن أبي هريرة. }
$$

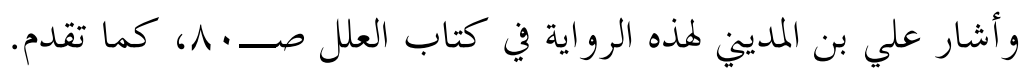

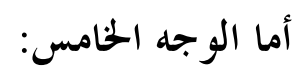

\section{(الزهري، عن سعيد بن المسيب، عن أبي هريرة)}

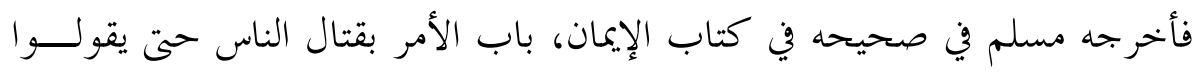

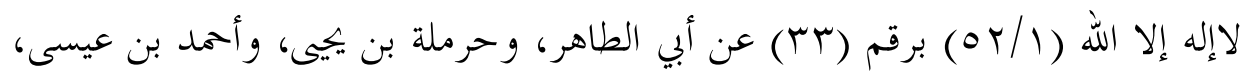
كلهم عن ابن وهب، عن يونس، عن الزهري، به، بنحوه.

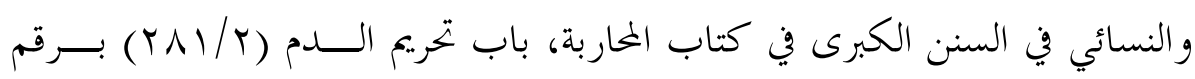

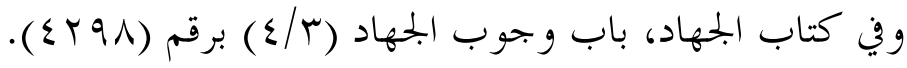

$$
\begin{aligned}
& \text { وفي المختى في أول كتاب الجهاد (7/ه). } \\
& \text { و الدار قطني في العلل (9/9 عه 1). } \\
& \text { و الطحاوي في شرح معاني الآثار (r/T/T). }
\end{aligned}
$$




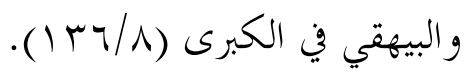

جميعهم من طريق ابن وهب، عن يونس، عن الزهري، عن سعيد بن المسيب، عن أبي هريرة، بنحوه. وقد تابع يونس بن يزيد كل من:

$$
\text { ا - شعيب بن أبي حمزة: }
$$

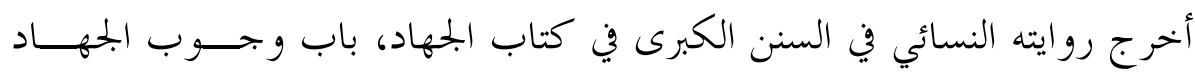
(T/r/T) وفي المختى في أول كتاب الجهاد (V/T)

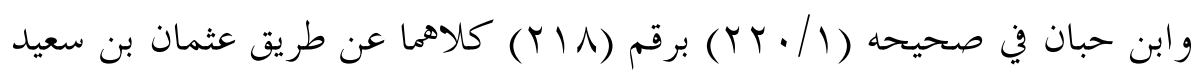

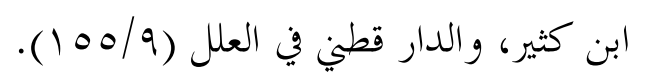

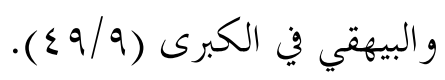

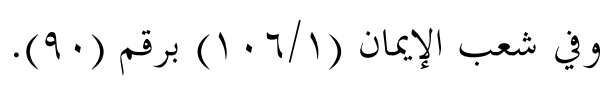

ثلاثتهم من طريق أبي اليمان الحكم بن نافع.

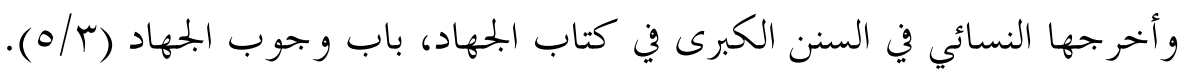

$$
\text { و المحتى في أول كتاب الجهاد (T/7) من طريق الوليد بن مسلم. }
$$

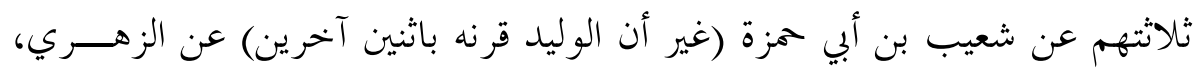

$$
\text { عن سعيد بن المسيب، عن أبي هريرة، بنحوه. }
$$

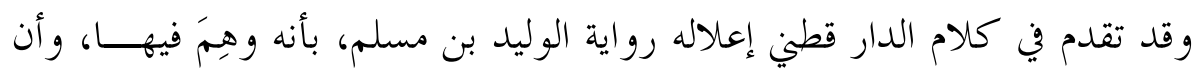

$$
\text { الصحيح: عن شعيب، عن عبيد الله، عن أبي هريرة. }
$$

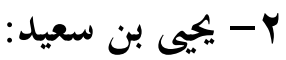

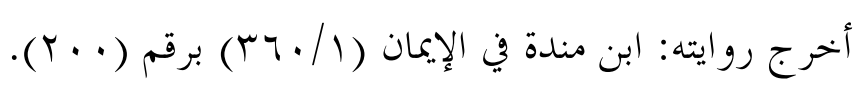

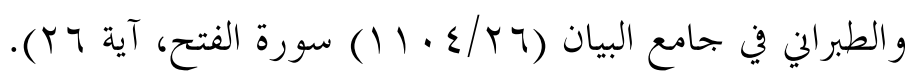


و البزار في مسنده (رسالة دكتوراه اللحياني) (1/1/1/) برقم (1 إع). ثلاثتهم عن طريق إسماعيل بن أبي أويس، عن أخيه، عن سليمان بن بلال، عن ييى ابن سعيد، عن الزهري، عن سعيد بن المسيب، عن أبي هريرة، بنحوه. r- عبد الرحم بن خالد بن مسافر:

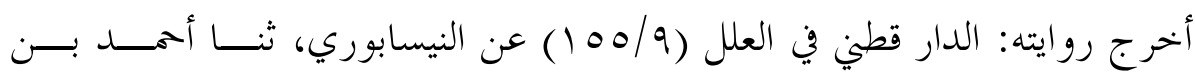
عبدالرحمن، ثنا عمي (عبدالله بن وهب المصري)، عن الليث، عن عبدالرحمن بن خالد، عن ابن شهاب، به، بنحوه. ع- يجيى بن أبي أنيسة:

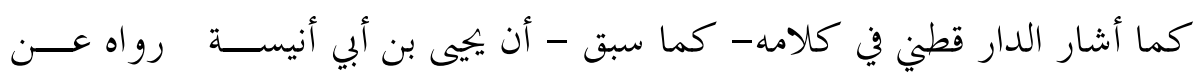

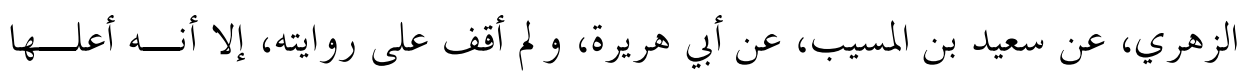

$$
\text { بقوله: ووهم - يعني: بيجى بن أبي أنيسة - في ذكر سعيد. }
$$

و لم أقف على روايته إلا في كلام ابن المديني - كما ســـق - الــــي قــال: رواه

$$
\text { صالح، عن ابن شهاب، عن ابن المسيب، عن أبي هريرة. }
$$

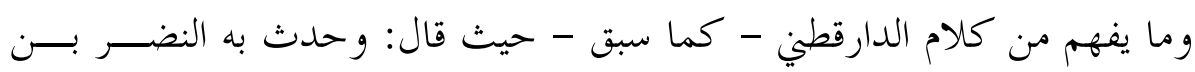

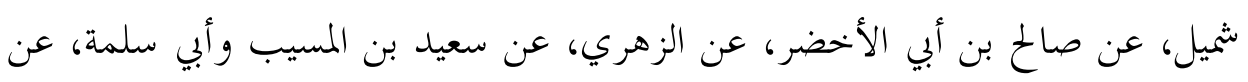

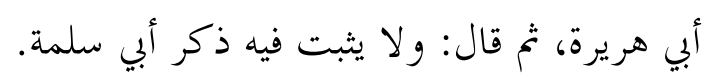

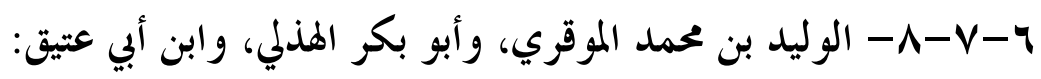

وقد أشار الدارقطني إلى روايتهم، و لم أقف عليها. أما الوجه السادس:

(الزهري، عن سعيد وأبي سلمة، عن أبي هريرة). فلم أجد من رواه عنه، غير صالح بن أبي الأخضر . 


$$
\text { أخرجه الدار قطني في العلل (100/9). }
$$

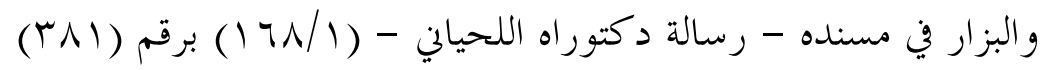

وقال: وهذا الحلديث، قد قال بعضهم عن أبي هريرة عن عمر، وقال بعضهم عــن أبي هريرة، ورواه غير واحد عن الزهري، عن عبيد الله، عن أبي هريرة. كلاهما من طريق صالح بن أبي الأخضر، عن الزهري، عن سعيد وأبي سلمة، عــنـ أبي هريرة، بنحوه.

وأشار إليها ابن المديني في العلل كما تقدم.

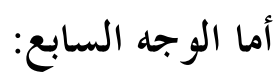
(الزهري، عن عمر مرسلاً) فلم أجد من رواه عنه غير سفيان بن عيينة.

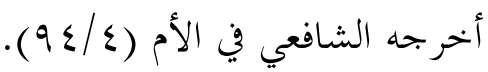

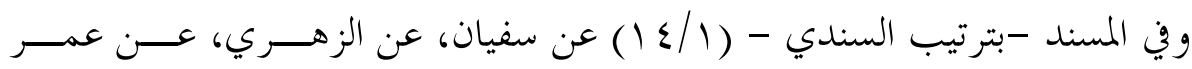
مرسالًا بنحوه.

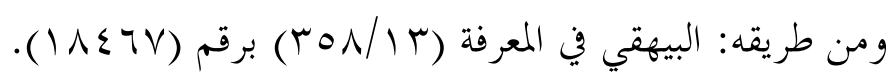

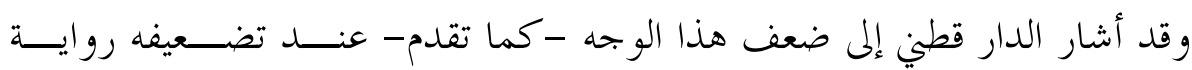
سفيان، عن سعيد ابن المسيب، عن أبي هريرة، فقال:... وابن عيينة يرويه عن الزهري مرسلاً، لا يذكر فوقه أحداً. كما أشار إليها ابن المديني في العلل ص •1 - كمما تقدم- حيث قال: ورواه ابــن

$$
\text { عيينة عن [الزهري] (1) مرسلاً. }
$$

(1) في المطبوع "أبي هريرة" والصواب ما أثبتـه، والظاهر أها تصحيف. 


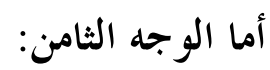

\section{(الزهري، عن عبيد بن عمير، عن أبي هريرة):}

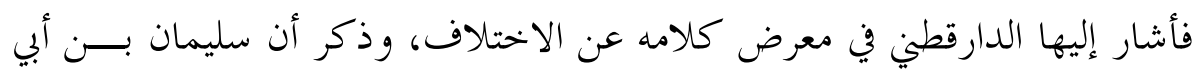

داود الحراني رواه عن الزهري، به.

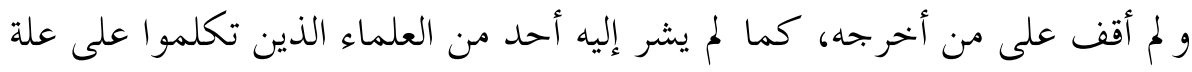

الحديث.

\section{النظر في الاختلاوف}

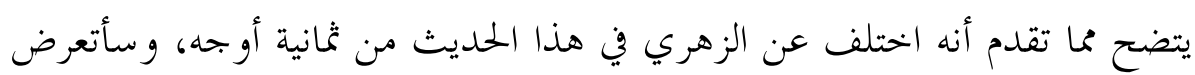

لهذا الاختلاف، وبيان نتيجته كما يلي:

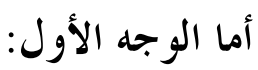

(الزهري، عن عبيد الله، عن أبي هريرة، عن عمر):

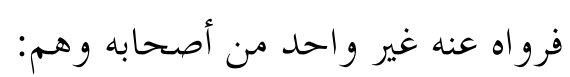

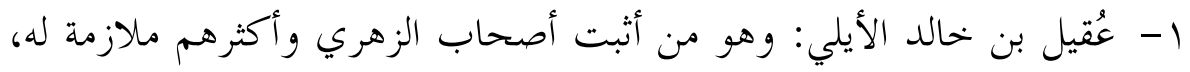

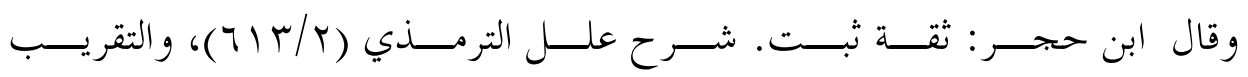
. ( $\{770 / \% 97)$

r- يونس بن يزيد: هو الأيلي، من أصحاب الزهري الملازمين له، وابن حجـــر

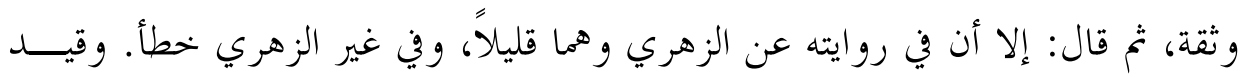
ابن المديني كونه أثبت الناس عن الزهري بما إذا حدث من كن إنابه.

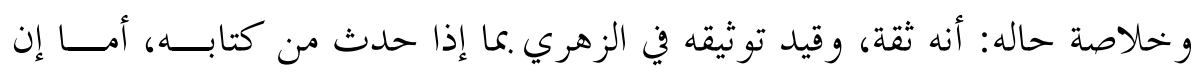
حدث من حفظه فقد يهم فيه.

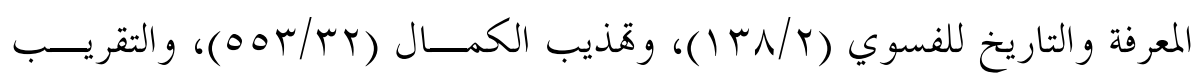


r- شعيب بن أبي همزة، كان من الملازمين للإمام الزهري من أثبـــت أصــحابه،

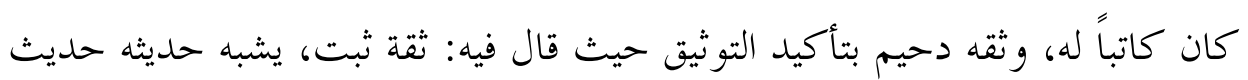

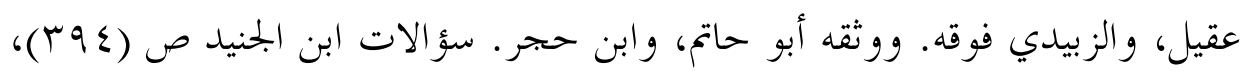

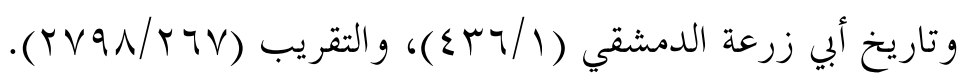

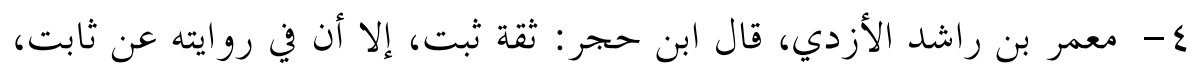

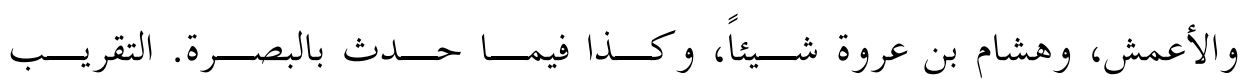
.$(71 \cdot 9 / 0 \leqslant 1)$

ه- محمد بن الوليد الزبيدي: من الطبقة الأولىمن أصحاب الزهري الذين تميزوا

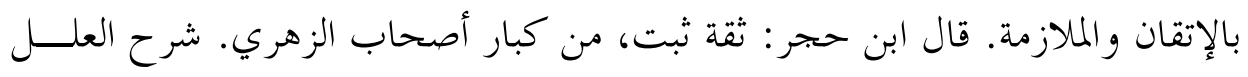

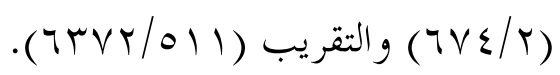

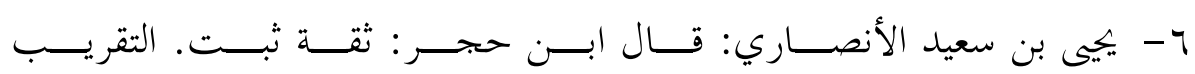
. $(1009 / 091)$

V - عبدالرحمن بن خالد بن مسافر: من الطبقة الثانية من أصحاب الزهري الذين

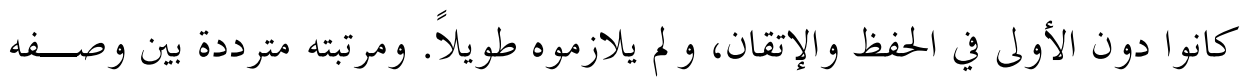

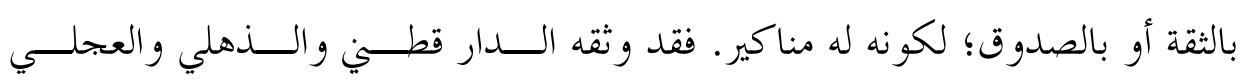

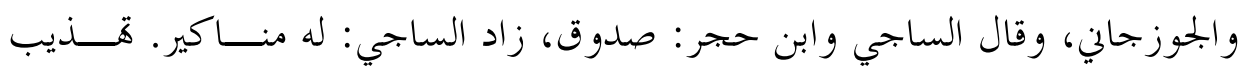

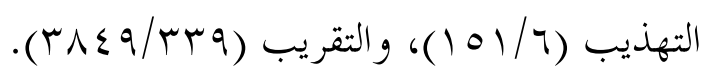

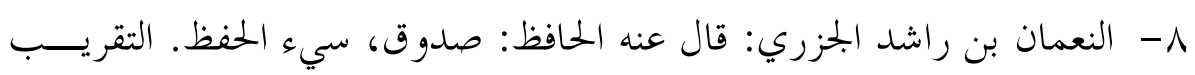
. (V/O $107 \varepsilon)$

9- محمد بن إسحاق بن يسار: اختلف العلماء فيه اختلافاً كبيراً، وخلاصة حاله:

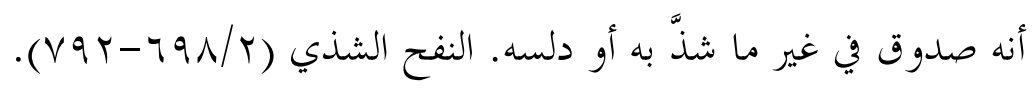

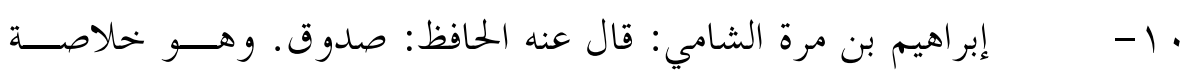




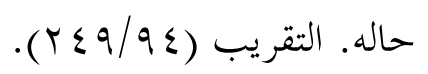

سفيان بن حسين الو اسطي:اختلف العلماء فيه، وخلاصة حاله كما

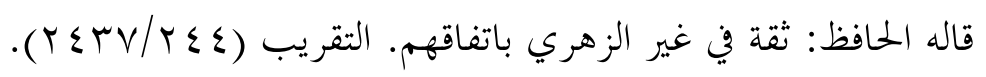

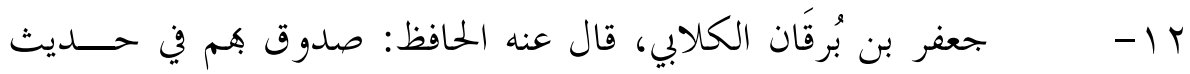

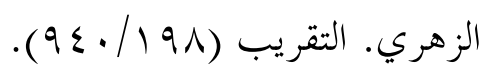

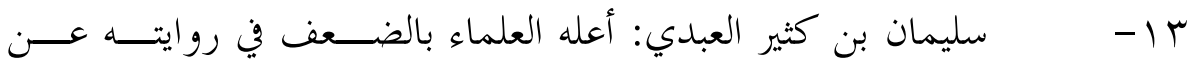
الزهري، حيث قال النسائي وبنحوه قال ابن حجر: ليس به بأس، إلا في الزهري، فإنه

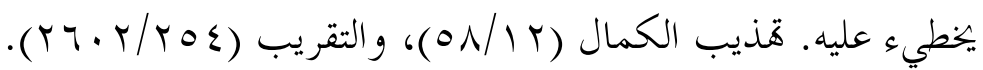

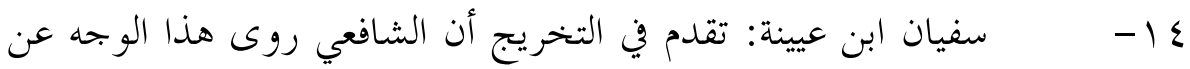

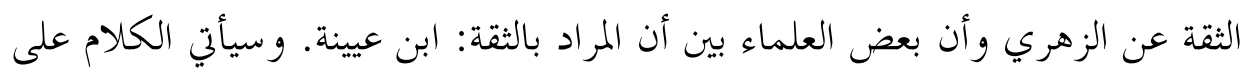
سفيان والاختلاف الذي حصل عنه في دراسة الوجه السابع.

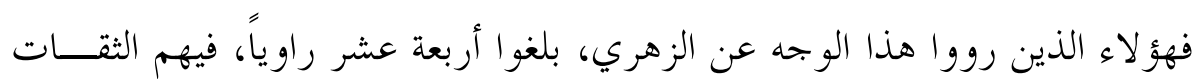
الذين وصفوا بأهم من أثبت أصحاب الزهري. ويمكن القول بأن هذا الوجه من أرجح الأوجه وأحفظها، لرواية هؤلاء الثقات من بن

$$
\text { أصحاب الزهري، و كثرةم. }
$$

ولهذا صوَّب الإمام الدارقطني هذا الوجه، وو افقه عدد من النقاد، تقدم ذكرهم: (علي بن المديني، و النسائي، والخطيب البغدادي، وأبو حاتم، وأبو زرعة الرازيــان،

$$
\begin{aligned}
& \text { وأبو محمد الغساني). }
\end{aligned}
$$

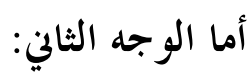

$$
\begin{aligned}
& \text { (الزهري، عن عبيد الله، عن عمر بدون أبي هريرة): } \\
& \text { فرواه عن الزهري راو يان هما معمر بن راشد، وسفيان بن حسين. }
\end{aligned}
$$


أما رواية معمر بن راشد:

فهذا الوجه ثاني الأوجه التي رواها في الحديث، إذ سبق أن روى الوجه السابق وقد روى هذا الوجه عنه: عبدالززاق بن همام، من رواية إسحاق الدبري عنه.

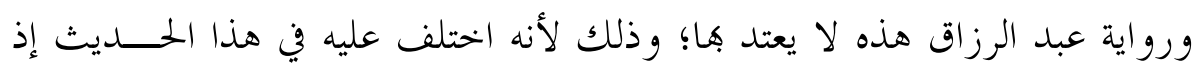

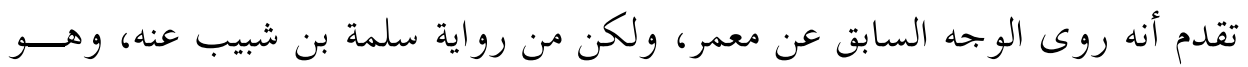
أرجح من رواية إسحاق الدبري عنه، لثلاثة أمور:

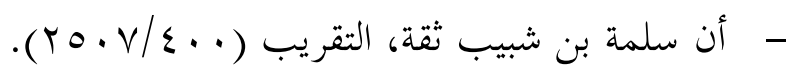

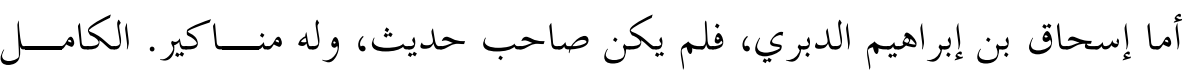

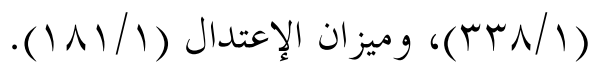

- - صرح الحافظ العراقي بأن رواية سلمة بن شبيب عن عبدالرزاق قبل الاختلاط،

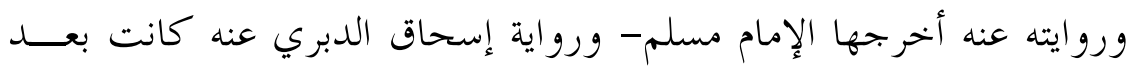

$$
\text { الاختلاط. التقييد والإيضاح صــ م • ع. }
$$

$$
\text { جـ- عبدالرزاق توبع في رواية الوجه الأول براويين، وهما: }
$$

- رباح بن زيد الصنعاني، قال عنه الحافظ: ثقة فاضل، كان له علم بحديث معمر.

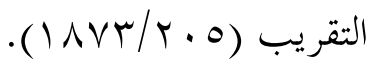

- وومطرف بن مازن، الثقة عند الشافعي، كما تقدم في روايته (حـــثنا الثقـــة)،

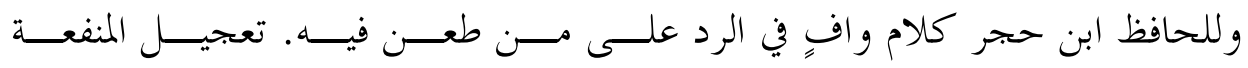
(صع • ع -ه • ع). بينما لم يتابع في الوجه الثاني. أما رواية سفيان بن حسين: فهي غير محفوظة؛ لأمرين:

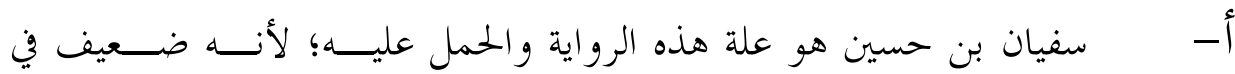
الزهري، كما تقدم الحلكم عليه. وأما الراوي عنه فهو، يزيد بن هارون الو اسطي، قال 


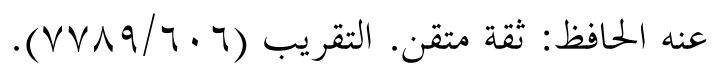

ب- - أنه روى الحديث على الجادة كما في الوجه الأول. وبناء على ما تقدم من ضعف روايتي معمر وسفيان يتضح عدم رجحان هذا الوجه عن الزهري، و الله أعلم.

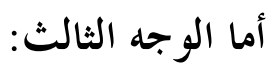

$$
\text { (الزهري، عن عبيدالله، عن أبي هريرة مرفوعاً): }
$$

1- سفيان بن حسين: من رواية محمد بن يزيد الو اسطي عنه، وقد تقــــدم بيــان

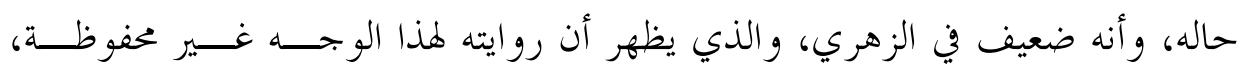
والحمل عليه، وقد سبق بيان أنه روى الوجه الأول على الجلادة كما تقدم.

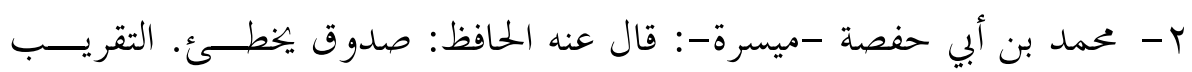
(ON Y T/\&V \&) أخطائه. وبناء على ما تقدم من ضعف الراويين لهذا الوجه عن الزهري، يمكن القول بأنــه غير محفوظ عنه.

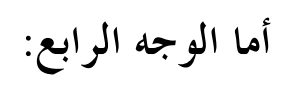

\section{(الزهري، عن أنس، عن أبي بكر):}

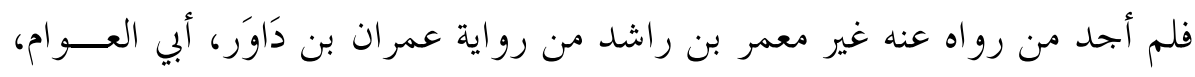

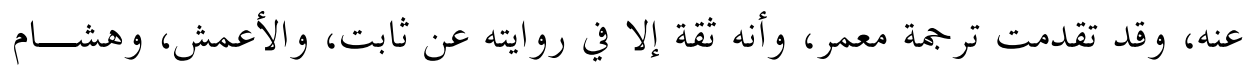

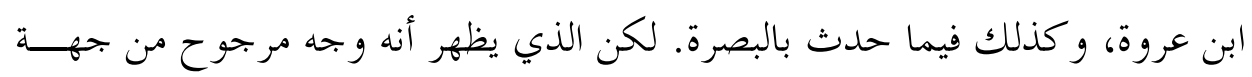
عمران بن دَاوَر، أبي العوام، قال عنه الحافظ: صدوق يهم. 


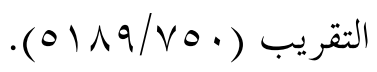

وقد خالف الأكثر والأوثق؛ ولذلك أعل غير واحد من العلماء هذا الوجه، وحملوا العلة على عمر ان هذا، كما تقدم في التخريج.

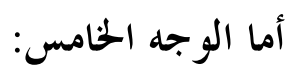

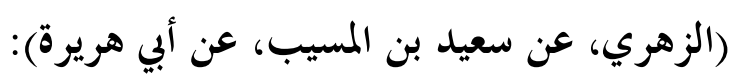
فرواه أكثر من واحد من أصحابه عنه:

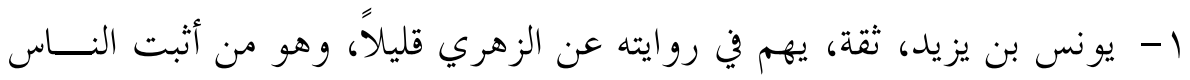
فيه إذا حدث من كتابه، وقد تقدم. r- شعيب بن أبي حمزة: ثنقة ومن أثبت الناس في الزهري، وقد تقدم.

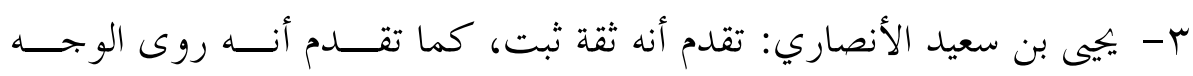

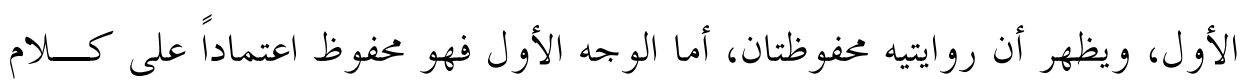

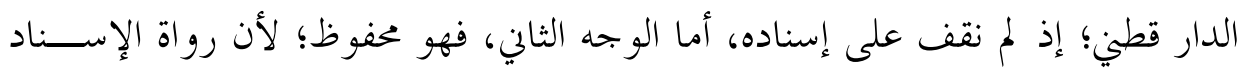
وتحته ثقات. ع - عبدالرحمن بن خالد بن مسافر، وهو ثقة، له بعض المناكير. وقــــ تقـــدم في الوجه الأول، وروايتاه محفوظتان و الله أعلم.

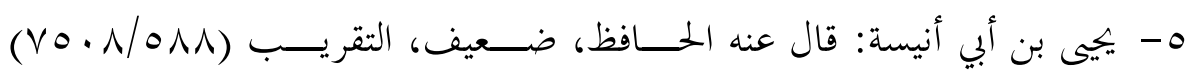
وروايته غير محفوظة لأمرين:

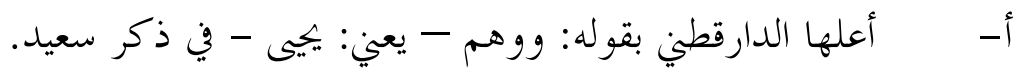

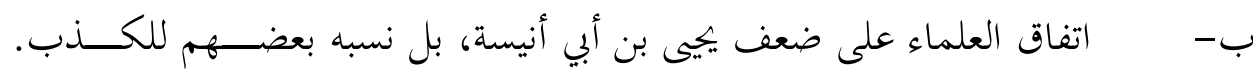

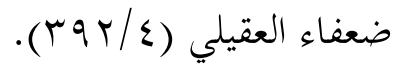
7- صالح بن أبي الأخضر اليمامي: قال البخاري: لـــن في الزهــــي. وضــفه 


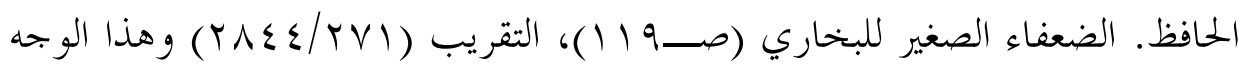
هو المحفوظ عنه لموافقته الثقات، وسيأتي أنه روى الوجه السادس وهو وجهه مرجــوح أعله الدارقطني.

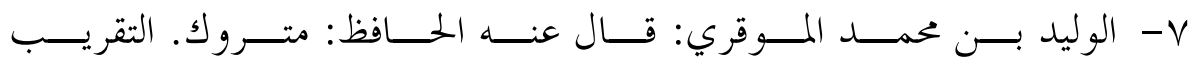

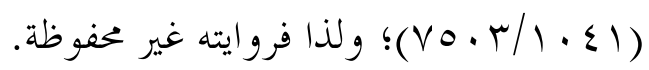

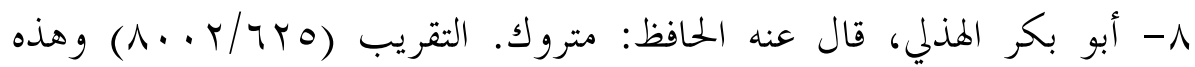
الرواية غير محفوظة. 9- ابن أبي عتيق: هو محمد بن عبدالله التيمي. قال الذهلي: حسن الحلديث عـــن

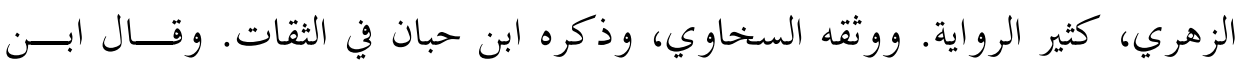
حجر: مقبول. و الذي يظهر -و الله أعلم-: أنه صدوق كما قال الذهلي إذ؛ لم يضعفه

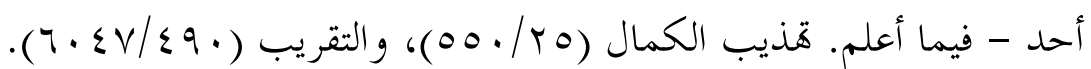
فالحلاصة أن هذا الوجه محفوظ، لرواية جمع من الرواة عن الزهري، منهم الثقات،

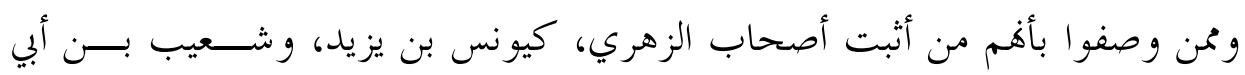
حمزة، ومن تابعهم من الثقات؛ ولذلك صوبه الدار قطني في العلل، كما سبق.

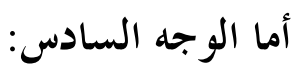

\section{(الزهري، عن سعيد وأبي سلمة، عن أبي هريرة):}

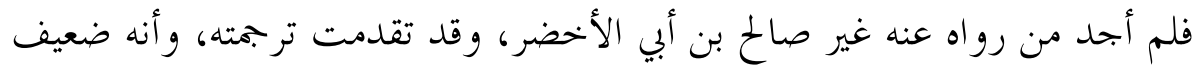
في الزهري، وفي غيره. - مين. ولذا فإن هذا الوجه مرجوح من ونئ روهاية صالح بن أبي الأخضر، وإنما الوجه الــــاجح

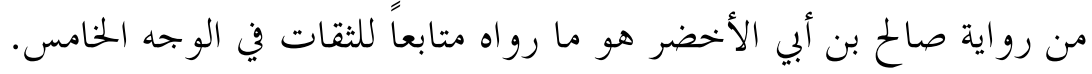
ولذلك أعل الدارقطين هذا الوجه - أعبن: الوجه السادس-بقوله: ولا يثبت فيــــ ذكر أبي سلمة. 
فلم أجد من رواه عنه غير سفيان بن عيينة، وقد سبقت ترجمته وأنه ثثة ثبت، وعد

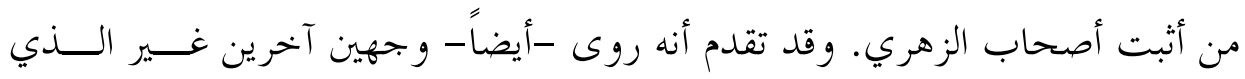
مضى.

والذي يظهر -و الله أعلم- أن الراجح من رواياته الثلاث الرواية المرسلة؛ لأمرين: 1- توهين الدارقطني روايته الوجه الخامس(الزهري، عن سعيد، عن أبي هريـــرة

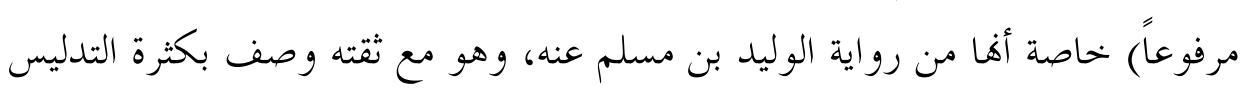

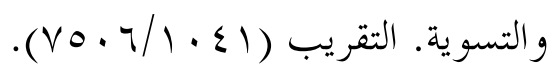

قال الدارقطين كما سبق: ووهم -ـيعني: الوليد بن مسلم- على شــيب وعلـى ابن عيينة.

r- قال الدار قطني: وابن عيينة يرويه عن الزهري مرسلاً لا يذكر فوقه أحسـداً.

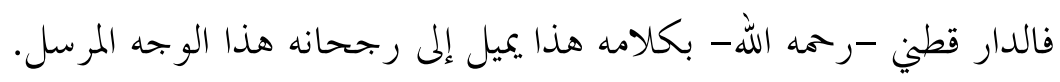
ثم إن هذا الوجه المرسل - الراجح بين الأوجه الثلاثة - مرجوح بين الأوجه الــتي اختلف فيها عن الزهري، وذلك لأمور: - أن سفيان - مع إمامته وثقته - خولف بمن روى الوجه الأول والخامس وهم

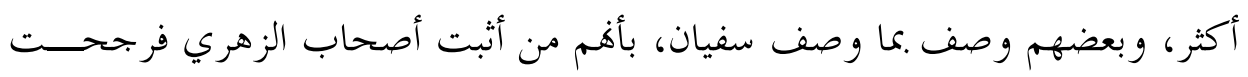
الكثرة.

r- أن العلماء الذين تكلموا على أوجه الاختلاف صوبوا الوجه الأول والخامس، وكأهم يضعفون ما سو اها، ومنها هذا الوجه. 


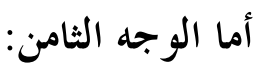

(الزهري عن عبيد بن عمير، عن أبي هريرة مرفوعاً): فلم أقف عليه إلا في كلام الدار قطني. ويظهر أنه وجه مرجوح- أيضاً -؛ وذلك لأن الراوي عن الزهري، هو سليمان بن

أبي داود الحراني، متفق على ضعفه. إذ قال البخاري: منكر الحديث.

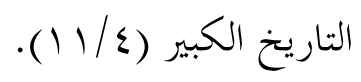

ووصفه أبو زرعة بأنه لين الحديث، وقال أبو حاتم: ضعيف الحديث جدا.

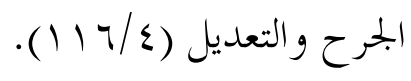

\section{الحخلاصة و الحكىم على الحديث}

نخلص مما سبق رجحان الوجه الأول (الزهري، عن عبيد الله، عن أبي هريرة، عــن عمر مرفوعاً).

$$
\text { و الوجه الخامس (الزهري، عن سعيد بن المسيب، عن أبي هريرة مرفوعاً). }
$$

ولذلك صو هما الدار قطني بقوله: وحديث سعيد بن المسيب هو الصحيح (يعسي:

$$
\text { الوجه الخامس)، وحديث عبيد الله بن عبدالله أيضاً (يعني الوجه الأول). }
$$

ثم إنه لا تعارض بين هذين الوجهين؛ إذ دفعه ابن حجر بالجمع بينهما، فقال: وهو

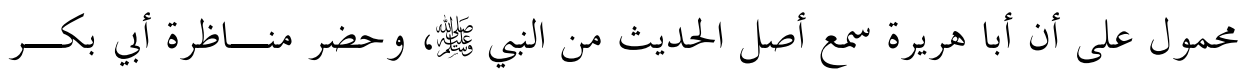

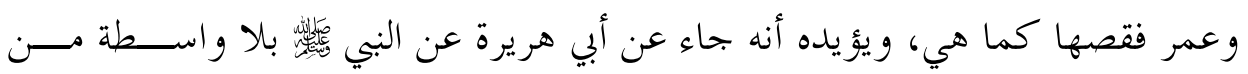

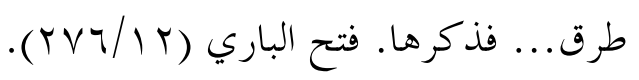

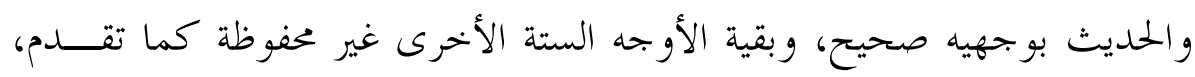
وصلى الله على سيدنا محمد وعلى آله وصحبه أجمعين. 


\section{الخاتهـت}

الحمد لله و حده و الصلاة و السلام على من لا بني بعده... و بعد

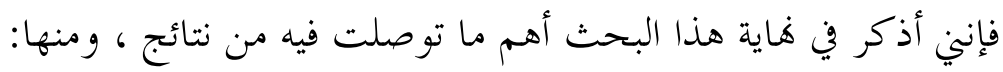

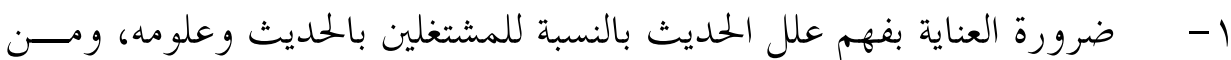
لا يحسنه و لا يفهمه لا يحل له الحكمى على الأحاديث حتى يتل يتعلمه ويفهمه.

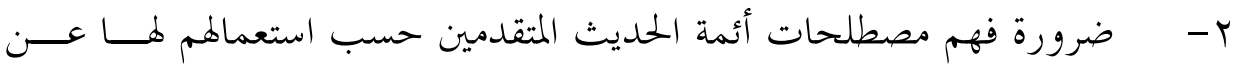
طريق الجمع و الاستقراء و الدراسة و والموازنة.

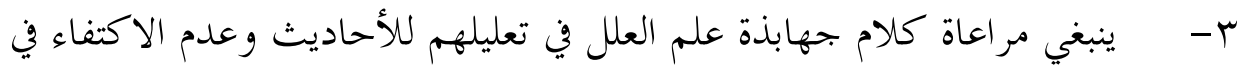

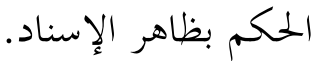

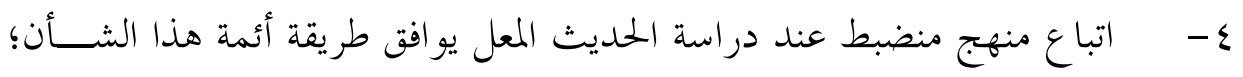

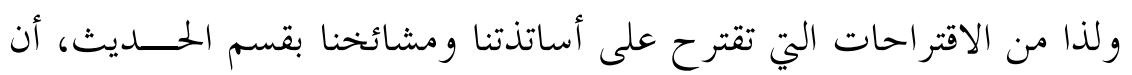

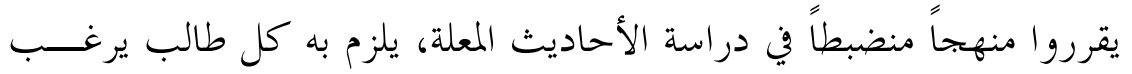

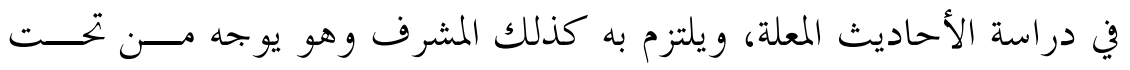
إشر افه، مع مراعاة الكم و الكيف.

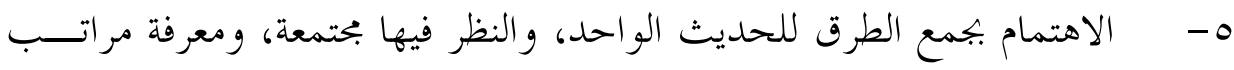

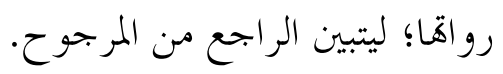

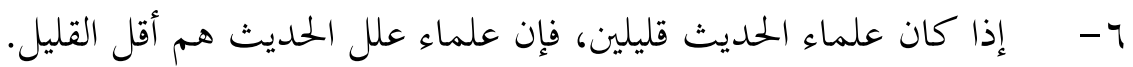

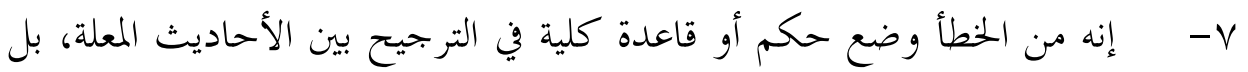

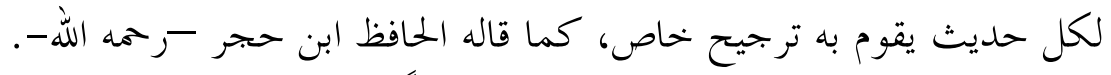

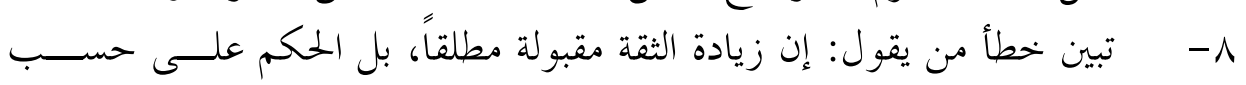
القر ائن. هذا وأسأل الله أن يعلمنا ما ينفعنا وأن ينفعنا بما علمنا، إنه سميع بجيب. وصلى الله على نبينا محمد وعلى آله وصحبه أجمعين والحمد لله رب رب الهمان العالمين. 


\section{فهرس المراجع \\ (خاص بالفصل الأول)}

1- الإرشاد في معرفة علماء الحديث: للإمام الخليلي، تحقيق: محمد سعيد إدريس،

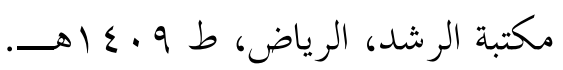

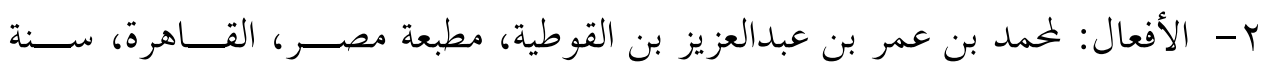
. 1904

r- ألفية السيوطي: بتحقيق: أحمد محمد شاكر، عالم الكتب - بيروت. ع - تاريخ بغداد: للخطيب البغدادي، المكتبة السلفية - المدينة.

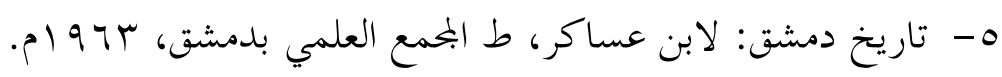

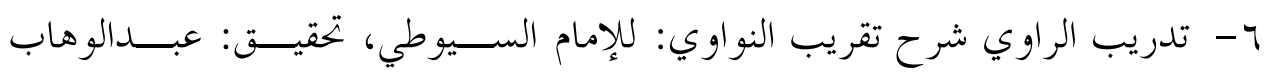

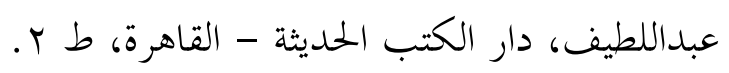

V- التدوين في أخبار قزوين: عبدالكريم بن محمد القزويني، تحقيق: عزيز الله العطاري،

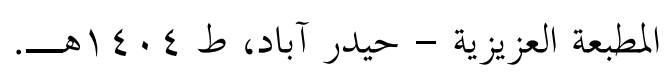

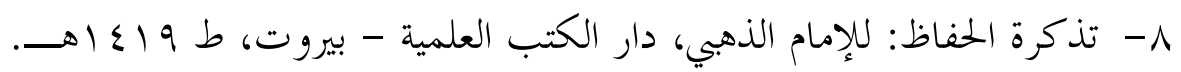

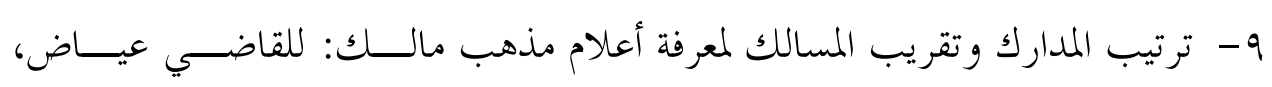

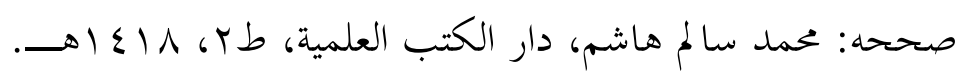

$$
\text { • } 1 \text { - التمييز: للإمام مسلم بن الحجاج. }
$$

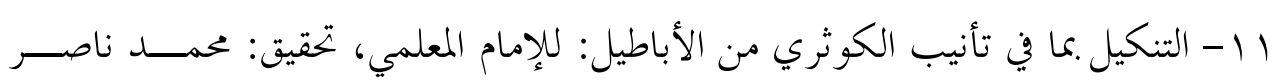

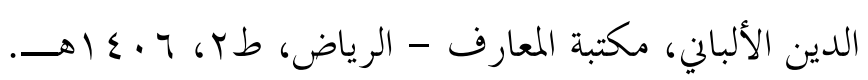

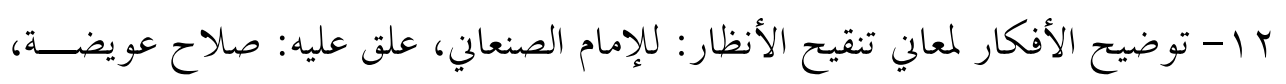

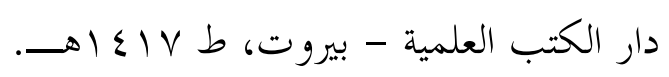


rا - جامع العلوم والحكم: لابن رجب، دار ابن الجوزي - الدمام، ط • إـاهـــ. ع ا - الجامع لأخلاق الراوي وآداب السامع: للخطيب البغدادي، تحقيق: محمد عجـــاج

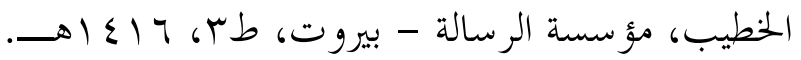

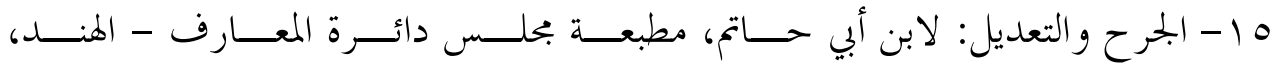
طו

7 ا 1 الرسالة والمتون الحديثة: لمحمد ابن الشيخ العلامة علي بن آدم الأثيوبي، دار آل بروم

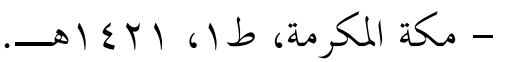

IV - سير أعلام النبلاء: للإمام الذهبي، تحقيق: شعيب الأرناؤوط، مؤسسة الرســالة -

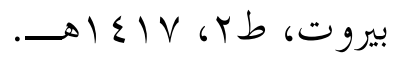

1 ا - شرح علل الترمذي: لابن رجب الحنبلي، تحقيق همام عبدالرحيم ســعيد، مكتبــة

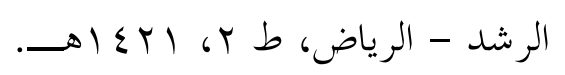

9 1 - شرح علي القاري على شرح نخبة الفكر لابن حجر: لعلي بن ســلطان الهـــروي

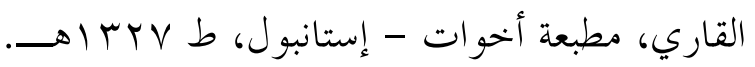

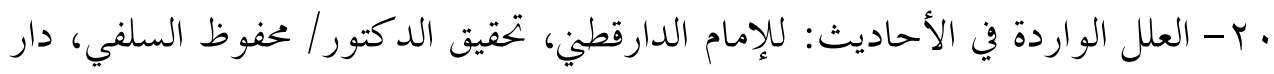

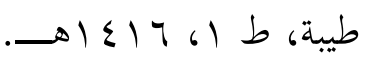

اب - علوم الحديث (مقدمة ابن الصلاح)، تحقيق: نور الدين عتر، دار الفكر المعاصــر -

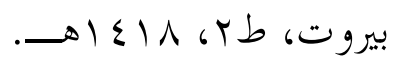

r r - فتح الباقي بشرح ألفية العراقي: لزكريا بن محمد الأنصاري، تحقيق: حافظ ثناء الله

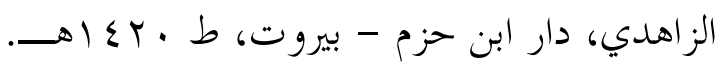
بr - فتح المغيث شرح ألفية الحديث: للإمام السخاوي، دار أحد. ع ب- فتح المغيث شرح ألفية الحديث: للإمام العراقي، تحقيق الشيخ سليمان ربيع، طال، اله . 1 1 100 


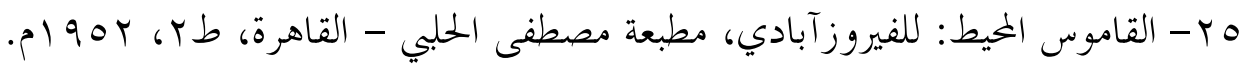

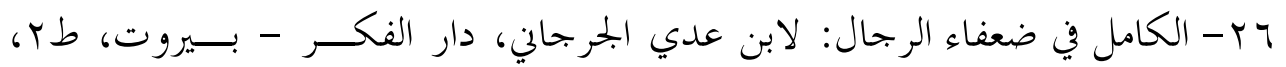

\section{$. \rightarrow \leqslant .0$}

VV - الكفاية في علم الرواية: للخطيب البغدادي، المكتبة السلفية - المدينة. م ץ - البحرو حين من المحدثين و الضعفاء والمترو كين: لأبي حاتم محمد بن حبــان، تحقيــق:

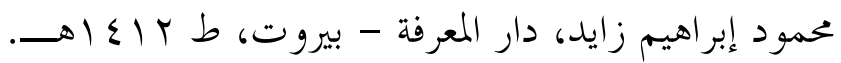
و r - معجم مقاييس اللغة: لابن فارس، طبع مطبعة مصطفى الحلبي - القاهرة. • ب- معرفة علوم الحديث: للإمام الحاكم النيسابوري، تصحيح: معظــــم الحســين، دار

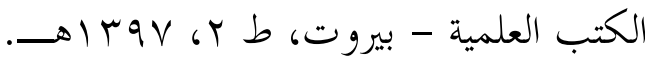
ابr- نــزهة النظر شرح نخبة الفكر: للحافظ ابن حجر.

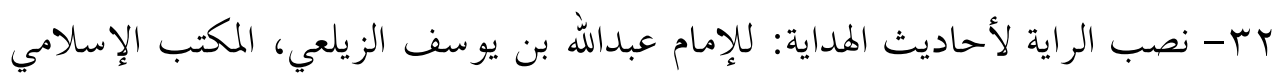
- بيروت، ط ץ، بو س اهــ. بr- نظم الفرائد لما تضمنته حديث ذي اليدين من الفوائد: للإمام صلاح الدين العلائي،

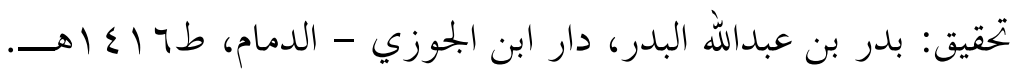

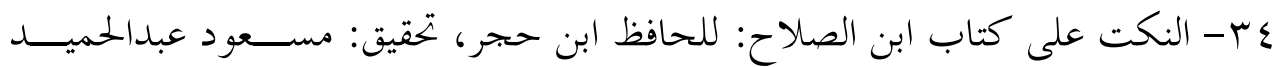

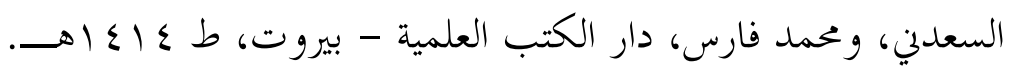


